IZA DP No. 5367

The Production of PhDs in the United States and Canada

Barry R. Chiswick

Nicholas Larsen

Paul Pieper

December 2010 


\title{
The Production of PhDs in the United States and Canada
}

\author{
Barry R. Chiswick \\ University of Illinois at Chicago \\ and IZA
}

Nicholas Larsen

University of Illinois at Chicago

Paul Pieper

University of Illinois at Chicago

\author{
Discussion Paper No. 5367 \\ December 2010
}

\author{
IZA \\ P.O. Box 7240 \\ 53072 Bonn \\ Germany \\ Phone: +49-228-3894-0 \\ Fax: +49-228-3894-180 \\ E-mail: iza@iza.org
}

\begin{abstract}
Any opinions expressed here are those of the author(s) and not those of IZA. Research published in this series may include views on policy, but the institute itself takes no institutional policy positions.

The Institute for the Study of Labor (IZA) in Bonn is a local and virtual international research center and a place of communication between science, politics and business. IZA is an independent nonprofit organization supported by Deutsche Post Foundation. The center is associated with the University of Bonn and offers a stimulating research environment through its international network, workshops and conferences, data service, project support, research visits and doctoral program. IZA engages in (i) original and internationally competitive research in all fields of labor economics, (ii) development of policy concepts, and (iii) dissemination of research results and concepts to the interested public.
\end{abstract}

IZA Discussion Papers often represent preliminary work and are circulated to encourage discussion. Citation of such a paper should account for its provisional character. A revised version may be available directly from the author. 
IZA Discussion Paper No. 5367

December 2010

\section{ABSTRACT \\ The Production of PhDs in the United States and Canada}

This paper is concerned with the production of PhDs in the United States and Canada in the post-WW II period, overall and by gender and major discipline. The effects of the explanatory variables lagged six years are consistent with the model. Military conscription with educational exemptions and the Vietnam War increased male PhD production in the U.S., but have no effect for U.S. females or in Canada. Government expenditures on research and development enhanced PhD production, especially for males and in the physical sciences in the U.S. A higher rate of growth of non-farm productivity encouraged PhD production in the U.S., but not in Canada. The cyclical indicator, the adult male unemployment rate, has a weak positive effect for males in both the U.S. and Canada, suggesting that the negative effect of the opportunity cost of time was stronger than the positive wealth effect. Other variables the same, there has been an increase over time in $\mathrm{PhD}$ production for females, but there is no such trend for males. The result has been an increase over time in $\mathrm{PhD}$ production for both males and females, but the faster increase for females has narrowed the gender gap.

JEL Classification: $\quad$ I21, J24

Keywords: $\quad \mathrm{PhD}$, educational attainment, conscription, Korean War, Vietnam War, research funding

Corresponding author:

Barry R. Chiswick

Department of Economics

University of Illinois at Chicago

601 S. Morgan Street

Chicago, IL 60607-7121

USA

E-mail: brchis@uic.edu 


\section{Introduction}

From Colonial times to the present, it has been recognized that high-skilled workers are essential inputs in the economic growth of this country. The definition of high-skilled has changed over time from the skilled artisans of the colonial period to the highly-educated STEM (science, technology, engineering and mathematics) workers of today. The most highly skilled of these workers typically complete their formal schooling with a PhD degree. Yet, there has been remarkably little research on the determinants of the production of PhDs in the United States in the post-World War II period.

There has been a substantial growth in the number of PhDs awarded in the US over the past century, particularly after WWII, as shown in Table 1.

\section{Table 1:}

Average Number of PhDs Awarded Annually in the United States, by Decade, 1910-1919 to the present

\begin{tabular}{|cccc|}
\hline \multicolumn{1}{c}{ Decade } & PhDs & Decade & $\underline{\text { PhDs }}$ \\
\hline $1910-1919$ & 546 & $1960-1969$ & 16,284 \\
$1920-1929$ & 1,081 & $1970-1979$ & 32,094 \\
$1930-1939$ & 2,697 & $1980-1989$ & 31,948 \\
$1940-1949$ & 3,349 & $1990-1999$ & 40,377 \\
$1950-1959$ & 8,376 & $2000-2006$ & 41,998 \\
\hline
\end{tabular}

Sources:

- U.S. Department of Commerce, Historical Statistics of the United States, Colonial Times to 1970 House document-93 ${ }^{\text {rd }}$ Congress, $1^{\text {st }}$ session; no 93-78. Bureau of the Census Series H 751-765 Institutions of Higher Education-Degrees Conferred, by Sex: 1870 to 1970 for the years 1950-1966

- $\quad$ NSF Survey of Earned Doctorates/Doctorate Records File for years 1966-2006 (Web address: http://webcaspar.nsf.gov/). 
This paper is one of the first systematic analyses of the changes over time in the post-war period in the number of PhDs awarded annually in the United States and Canada. The analyses are performed separately by country, overall and separately by gender and major academic discipline (Physical or Natural Sciences, Social Sciences, Humanities, and Education). ${ }^{1}$

Section II is a review of the literature on the awarding of $\mathrm{PhD}$ degrees. The model is developed in Section III. The sources of the data for the US and Canada (PhDs awarded and the explanatory variables) are reported in Section IV. The empirical analyses, first for the US and then for Canada, are reported in Section V. While the Summary and Conclusions are presented in Section VI.

\section{Literature Review}

The annual numbers of $\mathrm{PhD}$ recipients in the United States increased at a rapid rate from 1950 to 1966 with a downswing during the 1970s, followed by a gradual increase from 1980 to 2005 (Figure 1). Since the 1980s around 50 percent of the growth of $\mathrm{PhD}$ production in the United States is attributed to temporary residents (foreign students) earning PhDs, primarily in the fields of mathematics, science, and engineering (Stephan, Black, Adams \& Levin 2002). Similar trends are seen for PhD recipients in Canada (Figure 1). The data also show that initially most PhDs awarded in the United States were earned by men born in the United States, but over time this changed as the percentage of both the foreign born and women $\mathrm{PhD}$ recipients rose. The literature that looks at the trends in PhD production in the United States generally focuses only on changes to one of the following factors: change in attrition rates and time-to-degree by gender and field of study, rising NSF funding, draft avoidance, the GI Bills for veterans, or

\footnotetext{
${ }^{1}$ For the purpose of this project Mathematics is included in the Physical Sciences and Psychology is included in the Social Sciences.
} 
changes to the PhD labor market. The literature that examines the interaction of several or all these factors is primarily Bowen and Rudenstine (1992), which looks at PhD production from 1954 to 1988, and Chiswick (2008), which explains PhD production among Jews compared to others from 1950 to 2004.

Figure 1:

PhD Production in the United States and Canada, Overall and by Gender, 1950-2006.

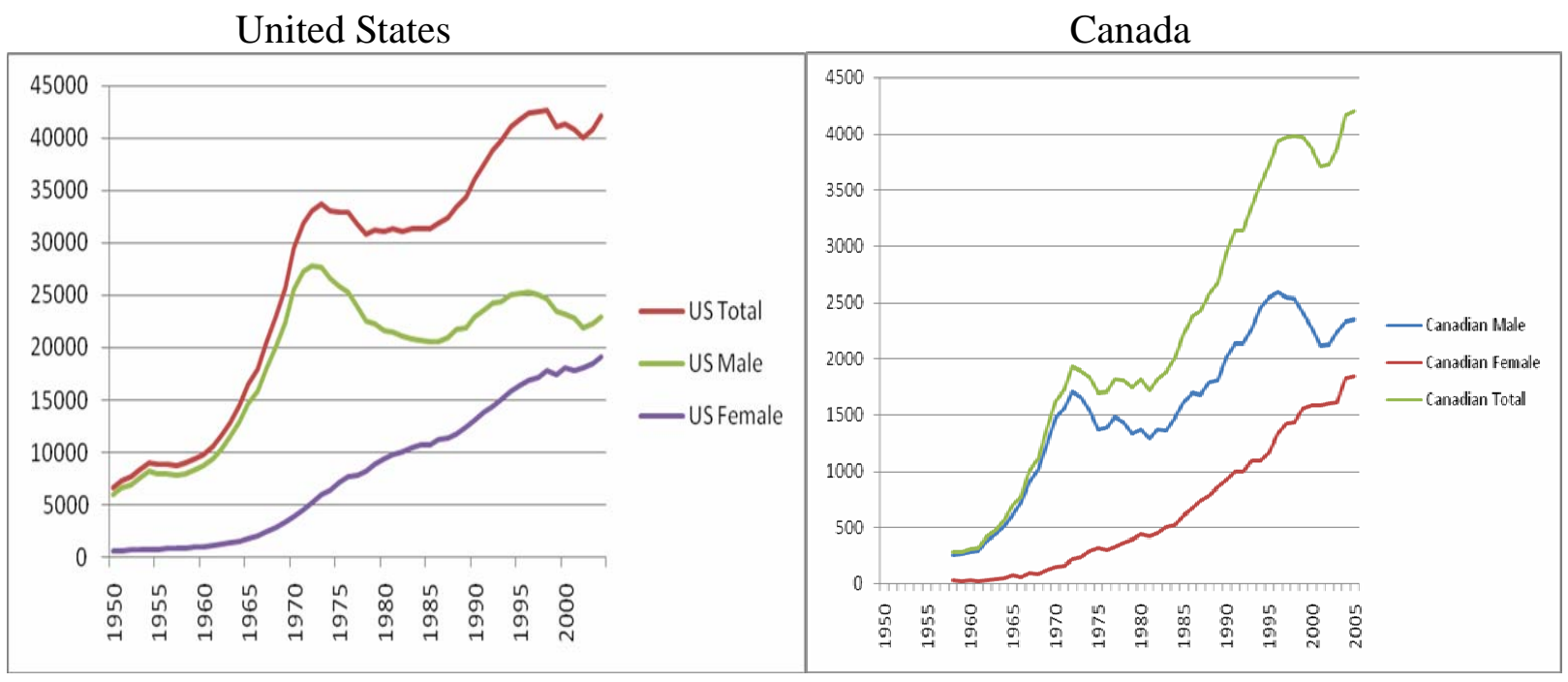

Sources:

1. Total number of Ph.D.s awarded in the U.S (by gender, by discipline, by ethnicity and in total)

- U.S. Department of Commerce, Historical Statistics of the United States, Colonial Times to 1970 House document-93 ${ }^{\text {rd }}$ Congress, $1^{\text {st }}$ session; no 93-78. Bureau of the Census Series H 751-765 Institutions of Higher Education-Degrees Conferred, by Sex: 1870 to 1970 for the years 1950-1966

- $\quad$ NSF Survey of Earned Doctorates/Doctorate Records File for years 1966-2006 (Web address: http://webcaspar.nsf.gov/).

2. Total number of Ph.D.s awarded in Canada (by gender and in total)

- Table W504-512 (Website address: http://www.statcan.gc.ca/pub/ 11-516x/sectionw/4147445-eng. htm) for years 1955-1973.

- Table 477-0014 available through CANSIM (Website address: http://cansim2. statcan.gc.ca/ cgi-win/CNSMCGI.EXE?LANG=Eng\& Dir-Rep=CII/\&CNSM-Fi=CII/CII_1-eng.htm) for years 1970-1997.

- $\quad$ CANSIM (Website address: http://library.queensu.ca/webdoc/ssdc/ xcleduc99.htm\#top) for years 1992-2005. 
Estimates of rates of attrition among $\mathrm{PhD}$ students, measured as the percent of students who do not graduate or continue studying from one year to the next, range from 40 to 50 percent, which is far greater than the 10 to 20 percent attrition found at the most selective of undergraduate programs (Berelson 1960; Bowen \& Rudenstine 1992; Lovitts 2001). The literature notes a difference between males and females in both time-to-degree and attrition rates. Women have a longer time to degree completion than men leading to a higher attrition rate, but these gaps have diminished over time within all degrees (Bowen \& Rudenstine 1992). The trend over time has been an increase in the total number of PhDs awarded annually, with a lower level but faster growth rate for women narrowing the $\mathrm{PhD}$ gender gap, especially in the social sciences.

The difference in the trends of men and women, along with differences in the fields of study, provide support for disaggregation of PhDs by gender and field. The aggregate downturn of $\mathrm{PhD}$ recipients in the 1970s is driven primarily by the decrease among native-born males. Bowen and Rudenstine (1992), for example, note that while the severe depression of academic jobs in the 1970s reversed the previous upward trend of PhDs; the number of PhDs earned in the U.S. by native born women and foreign born men and women continued to rise.

Furthermore, Bowen and Rudenstine observe systematic differences in the fields of study. For example, the completion rates, the percentage of an entering cohort that earn a PhD degree, of males in the sciences (65.3\%) is high compared to both the social sciences (55.7\%) and the humanities (51.8\%). Among women completion rates for a $\mathrm{PhD}$ in the sciences (58.8\%) is also high compared to both the social sciences (50.8\%) and the humanities (44.8\%). They also find that time to degree for humanities and social sciences degrees averages 8 years, while among the sciences it averages only 6.1 years (Bowen and Rudenstine 1992). 
The literature on the differences for why males and females entered PhD programs has focused primarily on two determinants, the increase in National Science Foundation (NSF) and other Federal funding after the launching of Sputnik in 1957 and the reaction of college age males seeking education deferments as the probability of conscription, and the probability of adverse consequences, increased during war time periods, especially the Vietnam War. The initial rise in doctoral degrees from 1954 to 1962 is attributed to two primary causes. Bowen and Rudenstine (1992), using data from the National Research Council, point to the launch of Sputnik in 1957 generating an increased public support for mathematics and sciences education in the United States. Increased support lead to more undergraduates entering these fields, with many continuing into graduate school. In a similar study on $\mathrm{PhD}$ production, focusing on American Jews, Chiswick (2008) observes that males appear to be more responsive to an increase in NSF funding than and females.

There is a relation between draft deferments and $\mathrm{PhD}$ program enrollment and completion. Initially explanations focused on the change in education draft deferments following the Selective Services Act of 1967. The Selective Services Act of 1967 reduced the number of deferments available to graduate students stating “... at the close of the 1967-1968 academic year, no more 2-S deferments would be granted to graduate students except those specifically written into law.” Marmion (1968) showed that draft deferments, even if limited to undergraduates, would lead to an increase in the number of male students going to college for a $\mathrm{BA}$, and given that a $\mathrm{BA}$ is a requirement for entering a $\mathrm{PhD}$ program, the increase would have a secondary effect of increasing the pool of students eligible for graduate $(\mathrm{PhD})$ study.

Draft avoidance leading to an increase in college enrollment has been analyzed in a number of studies. Chiswick (2008) notes that a factor that is important in the decision of young 
males continuing onto graduate school is the likelihood of their being conscripted into the military. Chiswick's results for men are further supported by the non-responsiveness of women in his analysis to a conscription variable, because women are exempt from a draft. Davis and Dolbeare (1968) found that males took advantage of education draft deferments by increasing their undergraduate enrollment. Baskir and Strauss (1978) estimate the increase in undergraduate enrollment due to the draft was between 6 and 7 percent. This is supported by Bound and Turner (1999), using Census data, and Card and Lemieux (2001), using data from the 1973

Occupational Change in a Generation, where a small portion of the increase could be from GI Bill benefits, but most of the increase is attributed to draft avoidance. Card and Lemieux also noted that total college entry rates for young males rose from 54 percent in 1963 to 62 percent in 1968. But, they also observed that while draft avoidance lead to about an 8 percentage points increase in the proportion of males who entered college, the number of males who actually attained a BA degree only increased by 2 percentage points during this time. They concluded that draft avoidance explains only a part of the 1970s story and attention needs to be paid to the economic return to education which fell during this time.

Using a cob-web supply and demand labor market model, Freeman (1971) found that positive demand shocks in the labor market lead to increases in earnings for someone with a $\mathrm{PhD}$. This increased earnings enticed more people to enter graduate programs eventually decreasing their relative wages. A similar cob-web approach to the over and under supply of PhDs in the labor market has been used to explain trends in $\mathrm{PhD}$ production by Cartter (1965), Freeman and Breneman (1974), and W. Lee Hansen, et al. (1980).

Freeman (1975a and 1975b), and later by Bowen and Sosa (1989), attributes the rise in undergraduates continuing into graduate school to the increased returns to $\mathrm{PhD}$ education in the 
labor market. Yet, Bowen and Rudenstine (1992) suggest that the favorable academic labor market is secondary to the increasing pool of undergraduates. Their observation is that as the number of undergraduates increased, many universities started to rely more heavily on graduate teaching assistants. Because of this, universities started to provide more funding to graduate students and increased the number and size of existing PhD programs. Cartter (1965) looked at the importance of the size of the cohort of university age students for predicting the demand for teachers by universities, as a $\mathrm{PhD}$ is now generally a requirement to teach in a college or university. Cartter found that as the "baby boomers" started to enroll in colleges the demand for $\mathrm{PhD}$ graduates by universities grew faster than the supply. This resulted in favorable labor market conditions for PhDs and more students went onto graduate school, eventually leading to an apparent "over-supply" of PhDs by 1969.

For physics PhDs, Freeman and Breneman (1974) observed a reversal in the labor market from 1964 to 1973 . They observed that from 1964 to 1969 the real annual salaries for physics PhDs increased by 11.7 percent, but from 1969 to 1973 real annual salaries for physics PhDs fell by 23.1percent. Similarly, W. Lee Hansen, et al. (1980) forecasted that relative academic salaries would have to fall in the 1980s to account for an over-supply of PhDs. This is supported by Youn (2005) who finds that the launch of Sputnik in 1957 lead to a 9 percent annual increase in enrollment and a 10 percent increase in funding annually for higher education from 1957 to 1967. This rapid increase, Youn notes, leads to an oversupply of PhDs by the late 1970s, reducing PhD enrollment numbers. In later work, Cartter (1966, 1971, 1972, 1974, and 1976), and later supported by Bowen and Sosa (1989), predicted that the oversupply of PhDs by the end of the 1970s would weaken the job market for PhDs throughout the 1980s. 


\section{The Model}

The time series analysis of the $\mathrm{PhD}$ output of American and Canadian universities can conceptually be put in the context of a supply and demand framework.

An important factor is the alternative use of time. During the post-WWII period from 1948 to 1973, there was military conscription for young males (age 18 to 26). For most of this period draft deferments were available for full-time male students in accredited academic programs. A student who could secure annual deferments up to age 26 would be exempt from conscription. Among those who viewed compulsory military service as a cost, there would be gains to continuing their academic studies up to at least age 26, that is, to continue beyond the undergraduate degree for a master's or PhD. Once successfully enrolled in a PhD program, there would be an incentive to remain until the degree is completed, even if this extends beyond age 26.

The cost of compulsory military service would be greater the greater the unpleasantness of this service or the higher the probability of injury or death. Hence, the incentive to avoid conscription would be greater during wartime. Thus, variables for military conscription and for the Korean and Vietnam Wars would enter the demand by young males for a PhD, and hence PhD production or completion several years later. It is not likely that the Korean War, which started unexpectedly in June 1950 and ended in June 1953, would have much of an impact given its short duration and limited number of troops. The Vietnam War, on the other hand, involved a gradual build up of U.S. forces, involved a much greater number of US troops annually, and lasted far longer, although conscription ended in 1973 before the end of the war in 1975.

Note, however, that these draft and wartime variables would be expected to effect the demand decisions for males but not for females who were not subject to the draft. Note also that 
while these variables would influence the demand for a $\mathrm{PhD}$ among American men, these same variables for the US should not be relevant for an analysis of $\mathrm{PhD}$ production in Canada which did not have military conscription in the period under study.

When civilian labor market conditions are poor, recent labor market entrants, including new college graduates, experience a disproportionate burden of high unemployment and poor wage offers. This lowers the opportunity cost of continuing one's studies, and hence a higher unemployment rate would increase the demand for enrolling in a $\mathrm{PhD}$ program. The male unemployment rate can be used as a proxy measure of the state of the economy - higher unemployment rates would encourage enrollment in $\mathrm{PhD}$ programs, and hence the production of PhDs several years later when the recession is likely to be over. This effect might be tempered by the wealth effect of a recession—declining incomes increasing the difficulty of self financing the cost of graduate education.

The male unemployment rate reflects cyclical conditions, but secular trends also matter. In a dynamic economy in which productivity is rising rapidly, and is expected to continue to do so, those with greater schooling tend to earn more relative to those with lesser schooling. This may be due to their having higher levels of decision making or allocative skills (Schultz 1975). Alternatively, it may be that in the post-WWII period technological change has been skill biased, that is, it raises the productivity of high-skilled workers more than lower-skilled workers. If this were the case for the PhD relative to those with, say, merely a bachelor's degree, higher rates of productivity growth would increase the relative demand for the PhD. Again, productivity growth would be a predictor of $\mathrm{PhD}$ graduates several years later.

The demand for the $\mathrm{PhD}$ by individuals would be expected to be related to the economic attractiveness of obtaining a $\mathrm{PhD}$, that is, the earnings of $\mathrm{PhD}$ recipients relative to those without 
this degree, say, with only a bachelor's degree. Unfortunately, we have not located appropriate data for the entire sixty years of our study to include this variable in the empirical analysis. However the relative earnings of $\mathrm{PhD}$ recipients will be captured at least in part by our productivity variable.

The supply side of slots in universities for accepting PhD students is also relevant. In many fields $\mathrm{PhD}$ slots are made available by universities through externally funded Federal research grants. The grants may provide the funding for the research projects, centers or institutes that then create positions for PhD students, or the grants may provide direct support for the $\mathrm{PhD}$ students. One can view the external research resources as reducing the opportunity cost of being in a PhD program (demand side) and as expanding the number (supply side) of spaces that universities make available to $\mathrm{PhD}$ students.

A higher rate of growth of technology, that is, long term economic growth, may also provide public and private $\mathrm{PhD}$ granting institutions greater resources through government funding and philanthropic contributions. This greater funding may translate into expanding university educational programs, including $\mathrm{PhD}$ programs. The rate of growth of productivity in the economy can therefore be included in the equation for the supply of spaces for students in PhD programs.

Thus, using a simple supply and demand framework for a time series study, it is possible to identify variables that would be expected to shift one or the other equation for an analysis of the production of PhDs. It is not possible, however, to develop shift variables to identify statistically either the supply or demand equation. What can be estimated, however, is a time series reduced form equation based on the variables discussed in this section. 


\section{Empirical Analysis}

The econometric methods used to estimate the time series model are ordinary least squares (OLS) and the Cochrane-Orcutt (1949) method to adjust the ordinary least squares model for possible serial correlation in the error term. The dependent and explanatory variables are defined in greater detail and their sources are indicated in Appendix $\mathrm{A}^{2}$. The dependent variable in the estimating equations use the number of $\mathrm{PhDs}$ awarded annually overall and by gender and broad field of study for the US and overall for Canada. The explanatory variables used to estimate the time series model of PhD production in the post-war period in the US are: government research and development expenditure, conscription variable (annual conscription in the US), the Korean and Vietnam Wars, adult male unemployment rate, nonfarm productivity growth, and a time trend and its square. The explanatory variables are lagged six years. The median registered completion time for the doctorate degree in the U.S. averaged approximately six years in the post-war period.

\section{(A) United States}

The ordinary least squares estimation for the total production of PhDs in the United States can be found in Table 2. Research and development expenditures are positive and statistically significant in all cases, except where it is negative for women and not statistically significant for the field of education, which receives little government research and development funding. This is consistent with the hypothesis that following the Soviet Union's launch of Sputnik in 1957 the large increase in Federal government funding, especially in the sciences, enhanced PhD production.

\footnotetext{
${ }^{2}$ In Appendix A the variables used in the empirical analysis are defined, their sources are reported and their descriptive statistics are presented. The actual data used in the analyses are presented in Appendix B.
} 
The coefficient for the total PhDs in a year means that a one standard deviation increase in research and development expenditure increases the number of PhDs by 5,955. The largest partial effect by fields of study is in the physical sciences. A one standard deviation increase six years previously in research and development expenditures would result in a 4,431 increase in PhDs for physical sciences, approximately four times larger than in the humanities (a 1,053 increase in PhDs), approximately fifteen times larger than social sciences (a 283 increase in $\mathrm{PhDs}$ ), and approximately twenty times larger than in education (a 217 increase in $\mathrm{PhDs}$ ). Research and development expenditures also have a stronger effect on males than females, in large part because males are more likely to be in the physical science programs. For males a one standard deviation increase in research and development expenditures results in a 6,315 increase in PhDs, while a one standard deviation increase for women reduces PhDs by a statistically insignificant 426.

The military variables are dichotomous variables for both the Korean War and Vietnam War and a continuous variable for the number of males conscripted into the military. The hypothesis is that the wartime variables should have a positive coefficient for males who are using graduate school to avoid the war and a zero (statistically insignificant) coefficient for females who do not need the education deferment.

The Korean War was unanticipated and relatively short. The Korean War coefficients are statistically significant and negative for both males and in the humanities, statistically significant and positive for women, and not statistically significant for any of the other dependent variables (Table 2). The coefficients show that the Korean War contributed to a 2,692 decrease in the number of PhDs for males and a 1,363 increase in female PhDs.

The results for the Vietnam War and military conscription appear to tell a different story. 
The Vietnam War coefficients and the conscription coefficients are positive and statistically significant in all cases, except for females and the physical sciences. In addition to its effect through conscription, the Vietnam War variable itself explains a 1,987 increase in total PhDs, which is primarily the result of an increase in male PhDs by 1,742. For military conscription, a one standard deviation increase would result in a 1,554 increase in total PhDs, which is also primarily the result of an increase in male PhDs by 1,976. This is consistent with the hypothesis that males will take advantage of education deferments to avoid the military, and women do not need to do this as they are not subjected to the military draft. Conscription reached its peak during the Vietnam War in 1966. Combined with the Vietnam War dichotomous variable, this increased the total number of PhDs by 4,049 in 1972, or more than 12 percent of the total for that year. The inconsistencies between the Korean War results, on one hand, and the Vietnam War and conscription variables, on the other, may be explained by the short duration of the Korean War, three years, compared to the Vietnam War and conscription, twelve years and thirty years respectively. The Korean War also involved far fewer military personnel than the Vietnam War.

The adult male unemployment rate is a proxy for the state of the economy. The male unemployment rate is only statistically significant in explaining the production of $\mathrm{PhDs}$ for the physical sciences and education. A one standard deviation increase in the male unemployment rate is associated with a 400 increase in physical sciences PhDs and a 118 decrease in education PhDs. A recession has two effects on PhD production. First, a decrease in the opportunity cost of time that would have upward pressure on the demand for a PhD. And second, the family income effect or wealth effect, as the decreased means of financing the investment in a $\mathrm{PhD}$ will have downward pressure on $\mathrm{PhD}$ production. The income effect is muted in a recession for the sciences and the opportunity cost is reduced because most science $\mathrm{PhD}$ candidates are receiving 
financial support. Thus, a recession appears to increase science PhDs. A smaller proportion receives financial support in education, increasing the importance of the negative income effect which appears to dominate the decreased opportunity cost of time.

The growth of nonfarm productivity is positive and statistically significant for the total PhDs, males, social sciences, and education and not statistically significant for the other dependent variables for the US. A one standard deviation increase in nonfarm productivity growth will result in a 4,487 increase in total PhDs, a 3,924 increase in male PhDs, a 1,513 increase in social sciences PhDs, and a 2,698 increase in education PhDs. These results are consistent with the hypothesis that productivity increases in the United States tend to increase the rate of return from education, including PhD education.

The time trend variables indicate that the total production of $\mathrm{PhDs}$ is increasing at a decreasing rate for unmeasured reasons. The increase in total $\mathrm{PhDs}$ is attributed primarily to the significance of the time trend for females. Figure 1, for the United States, shows a steady increase in PhDs for women from 1950 to 2006, with little evidence of a slowdown, which is consistent with the observation that more women are entering high-skilled labor market positions. By field of study, the time trend variables show that both the Humanities and Social Science have been increasing at a decreasing rate, while both Physical Sciences and Education have negative time trends, though the decline is not statistically significant. 
Table 2: Ordinary Least Squares: Analysis

of PhD Production by Gender and Discipline, United States, 1950-2006

\begin{tabular}{|c|c|c|c|c|c|c|c|}
\hline \multirow[b]{3}{*}{$\begin{array}{c}\text { Independent } \\
\text { Variables } \\
\end{array}$} & \multicolumn{6}{|c|}{ Dependent Variables } & \\
\hline & \multirow[b]{2}{*}{ Total } & \multicolumn{2}{|c|}{ Gender } & \multicolumn{4}{|c|}{ Field of Study } \\
\hline & & Male & Female & $\begin{array}{l}\text { Physical } \\
\text { Science }\end{array}$ & $\begin{array}{c}\text { Social } \\
\text { Science } \\
\end{array}$ & Education & Humanities \\
\hline $\begin{array}{l}\text { Research and } \\
\text { Development } \\
\text { (trillions \$) }\end{array}$ & $\begin{array}{c}256 \\
(13.91)\end{array}$ & $\begin{array}{c}272 \\
(18.56)\end{array}$ & $\begin{array}{c}-18.4 \\
(-1.66)\end{array}$ & $\begin{array}{c}191 \\
(10.75)\end{array}$ & $\begin{array}{c}12.2 \\
(2.47)\end{array}$ & $\begin{array}{c}9.39 \\
(1.84)\end{array}$ & $\begin{array}{c}45.4 \\
(7.91)\end{array}$ \\
\hline Vietnam & $\begin{array}{c}1987.074 \\
(4.01)\end{array}$ & $\begin{array}{c}1742.479 \\
(4.43)\end{array}$ & $\begin{array}{l}269.035 \\
(0.9)\end{array}$ & $\begin{array}{c}-514.524 \\
(-1.08)\end{array}$ & $\begin{array}{c}695.934 \\
(5.27)\end{array}$ & $\begin{array}{c}1080.904 \\
(7.89)\end{array}$ & $\begin{array}{c}750.449 \\
(4.88)\end{array}$ \\
\hline Korea & $\begin{array}{c}-1248.677 \\
(-1.32)\end{array}$ & $\begin{array}{c}-2691.932 \\
(-3.57)\end{array}$ & $\begin{array}{l}1363.487 \\
(2.39)\end{array}$ & $\begin{array}{c}-542.751 \\
(-0.59)\end{array}$ & $\begin{array}{c}-63.3821 \\
(-0.25)\end{array}$ & $\begin{array}{c}-118.472 \\
(-0.45)\end{array}$ & $\begin{array}{c}-988.341 \\
(-3.36)\end{array}$ \\
\hline $\begin{array}{l}\text { Conscription } \\
\text { (millions) }\end{array}$ & $\begin{array}{l}7500 \\
(3.1)\end{array}$ & $\begin{array}{c}5900 \\
(3.07)\end{array}$ & $\begin{array}{l}1650 \\
(1.14)\end{array}$ & $\begin{array}{c}-73.1 \\
(-0.03)\end{array}$ & $\begin{array}{l}2610 \\
(4.05)\end{array}$ & $\begin{array}{l}1800 \\
(2.69)\end{array}$ & $\begin{array}{l}1940 \\
(2.59)\end{array}$ \\
\hline Year & $\begin{array}{l}360.200 \\
(2.18)\end{array}$ & $\begin{array}{c}-117.446 \\
(-0.9)\end{array}$ & $\begin{array}{c}471.453 \\
(4.75)\end{array}$ & $\begin{array}{c}-191.838 \\
(-1.21)\end{array}$ & $\begin{array}{c}300.250 \\
(6.83)\end{array}$ & $\begin{array}{c}282.366 \\
(6.19)\end{array}$ & $\begin{array}{l}-6.273 \\
(-0.12)\end{array}$ \\
\hline Year $^{2}$ & $\begin{array}{l}-4.0151 \\
(-3.43)\end{array}$ & $\begin{array}{l}-3.382 \\
(-3.63)\end{array}$ & $\begin{array}{l}-0.740 \\
(-1.05)\end{array}$ & $\begin{array}{l}5.328 \\
(4.72)\end{array}$ & $\begin{array}{l}-4.0867 \\
(-13.09)\end{array}$ & $\begin{array}{c}-6.091 \\
(-18.80)\end{array}$ & $\begin{array}{l}0.795 \\
(2.18)\end{array}$ \\
\hline $\begin{array}{l}\text { Male Unemployment } \\
\text { Rate }\end{array}$ & $\begin{array}{l}209.828 \\
(1.46)\end{array}$ & $\begin{array}{c}186.743 \\
(1.64)\end{array}$ & $\begin{array}{l}14.660 \\
(0.17)\end{array}$ & $\begin{array}{l}292.0368 \\
(2.11)\end{array}$ & $\begin{array}{l}-5.2048 \\
(-0.14)\end{array}$ & $\begin{array}{l}-86.367 \\
(-2.17)\end{array}$ & $\begin{array}{l}-34.581 \\
(-0.78)\end{array}$ \\
\hline $\begin{array}{l}\text { Non Farm } \\
\text { Productivity } \\
\text { Hours }\end{array}$ & $\begin{array}{l}202.368 \\
(2.06)\end{array}$ & $\begin{array}{c}176.963 \\
(2.27)\end{array}$ & $\begin{array}{l}34.558 \\
(0.59)\end{array}$ & $\begin{array}{l}-6.499 \\
(-0.07)\end{array}$ & $\begin{array}{l}68.251 \\
(2.61)\end{array}$ & $\begin{array}{c}121.684 \\
(4.49)\end{array}$ & $\begin{array}{l}-0.327 \\
(-0.01)\end{array}$ \\
\hline Constant & $\begin{array}{c}-7014.100 \\
(-1.78)\end{array}$ & $\begin{array}{c}-2369.907 \\
(-0.76)\end{array}$ & $\begin{array}{c}-4908.529 \\
(-2.07)\end{array}$ & $\begin{array}{l}2983.036 \\
(0.79)\end{array}$ & $\begin{array}{c}-3990.947 \\
(-3.80)\end{array}$ & $\begin{array}{c}-5955.154 \\
(-5.47)\end{array}$ & $\begin{array}{c}858.257 \\
(0.7)\end{array}$ \\
\hline Obs. & 50 & 50 & 50 & 50 & 50 & 50 & 50 \\
\hline Adj. R sq. & 0.994 & 0.986 & 0.994 & 0.978 & 0.991 & 0.987 & 0.967 \\
\hline DW-Stat & 1.061 & 1.429 & 0.484 & 0.699 & 1.154 & 1.431 & 0.925 \\
\hline
\end{tabular}

Notes: T-statistics are found in parentheses

For a sample of size 50 and 8 explanatory variables, the critical values for the Durbin-Watson Statistic are: $\mathrm{dl}=1.2$ and $\mathrm{du}=1.93$ at the $5 \%$ level (Savin and White 1977).

Source: see Appendix A. 
In the OLS regression in Table 2 the Durbin-Watson statistic suggests autocorrelation of the residuals in many of the equations. The Cochrane-Orcutt method is used to correct for possible serial correlation, as shown in Table 3. For most cases, except for physical sciences, the Cochrane-Orcutt method shows considerable improvement in the Durbin-Watson statistic. For the total number of PhDs the only important change between the two methods is that in the Cochrane-Orcutt method the nonfarm productivity variable is no longer statistically significant, although it does retain approximately the same magnitude. The difference between ordinary least squares and the Cochrane-Orcutt Method for total female PhDs is that the Korean War variable is no longer positively statistically significant, but nonfarm productivity is now statistically significant ${ }^{3}$. In the humanities totals, the variables for the Vietnam War, Korean War, induction, and year squared went from being statistically significant to being insignificant. For the education PhDs induction, the male unemployment rate, and nonfarm productivity went from being statistically significant to being insignificant. For physical sciences the only change is that the male unemployment rate is now not statistically significant.

In separate regressions not shown in this paper, we also estimated OLS regressions using an ARIMA model with a six-period lag error structure. We obtained substantially the same results for all variables, indicating the robustness of our results to alternative estimation techniques.

\footnotetext{
${ }^{3}$ The serial correlation of the error terms is much higher in the female regressions than in the male regression. This suggests that there is a high level of persistence in female $\mathrm{PhD}$ production in response to changes in the explanatory variables, although we do not have a good economic reason for why this should be the case.
} 


\section{Table 3: Cochrane-Orcutt Method: Analysis of PhD Production by Gender and Discipline, United States, 1950-2006}

\begin{tabular}{|c|c|c|c|c|c|c|c|}
\hline \multirow[b]{3}{*}{$\begin{array}{l}\text { Independent } \\
\text { Variables }\end{array}$} & & \multicolumn{6}{|c|}{ Dependent Variables } \\
\hline & \multirow[b]{2}{*}{ Total } & \multicolumn{2}{|c|}{ Gender } & \multicolumn{4}{|c|}{ Field of Study } \\
\hline & & Male & Female & $\begin{array}{c}\text { Physical } \\
\text { Science Total }\end{array}$ & $\begin{array}{c}\text { Social Science } \\
\text { Total }\end{array}$ & Education Total & Humanities Total \\
\hline $\begin{array}{l}\text { Research and } \\
\text { Development } \\
\text { (trillions \$) }\end{array}$ & $\begin{array}{c}232 \\
(8.00)\end{array}$ & $\begin{array}{l}263.4 \\
(13.79)\end{array}$ & $\begin{array}{c}1.3 \\
(.11)\end{array}$ & $\begin{array}{c}113 \\
(4.18)\end{array}$ & $\begin{array}{c}18.6 \\
(2.09)\end{array}$ & $\begin{array}{c}13.8 \\
(1.31)\end{array}$ & $\begin{array}{c}30.7 \\
(3.36)\end{array}$ \\
\hline Vietnam & $\begin{array}{c}1814.675 \\
(3.29)\end{array}$ & $\begin{array}{c}1666.346 \\
(3.72)\end{array}$ & $\begin{array}{c}246.623 \\
(1.36)\end{array}$ & $\begin{array}{c}140.940 \\
(0.34)\end{array}$ & $\begin{array}{c}471.282 \\
(3.21)\end{array}$ & $\begin{array}{c}661.397 \\
(4.11)\end{array}$ & $\begin{array}{c}235.202 \\
(1.71)\end{array}$ \\
\hline Korea & $\begin{array}{c}-1334.864 \\
(-1.26)\end{array}$ & $\begin{array}{c}-2204.413 \\
(-2.52)\end{array}$ & $\begin{array}{l}-0.558 \\
(-0.00)\end{array}$ & $\begin{array}{c}149.958 \\
(0.20)\end{array}$ & $\begin{array}{l}37.646 \\
(0.14)\end{array}$ & $\begin{array}{l}53.920 \\
(0.19)\end{array}$ & $\begin{array}{c}-237.113 \\
(-0.97)\end{array}$ \\
\hline $\begin{array}{c}\text { Conscription } \\
\text { (millions) }\end{array}$ & $\begin{array}{l}5850 \\
(2.32)\end{array}$ & $\begin{array}{l}5810 \\
(2.71)\end{array}$ & $\begin{array}{l}-1.01 \\
(-0.00)\end{array}$ & $\begin{array}{c}564 \\
(0.33)\end{array}$ & $\begin{array}{l}1180 \\
(1.86)\end{array}$ & $\begin{array}{c}911 \\
(1.35)\end{array}$ & $\begin{array}{c}832 \\
(1.45)\end{array}$ \\
\hline Year & $\begin{array}{l}401.943 \\
(2.02)\end{array}$ & $\begin{array}{c}-91.808 \\
(-.60)\end{array}$ & $\begin{array}{c}568.582 \\
(4.81)\end{array}$ & $\begin{array}{c}-541.457 \\
(-1.79)\end{array}$ & $\begin{array}{c}278.0524 \\
(4.39)\end{array}$ & $\begin{array}{c}345.522 \\
(2.86)\end{array}$ & $\begin{array}{c}-94.549 \\
(-0.75)\end{array}$ \\
\hline Year $^{2}$ & $\begin{array}{l}-4.215 \\
(-2.17)\end{array}$ & $\begin{array}{l}-3.563 \\
(-2.97)\end{array}$ & $\begin{array}{l}-2.798 \\
(-1.80)\end{array}$ & $\begin{array}{l}9.623 \\
(2.44)\end{array}$ & $\begin{array}{l}-3.653 \\
(-4.77)\end{array}$ & $\begin{array}{l}-5.190 \\
(-3.30)\end{array}$ & $\begin{array}{l}1.442 \\
(0.90)\end{array}$ \\
\hline $\begin{array}{c}\text { Male } \\
\text { Unemployment } \\
\text { Rate }\end{array}$ & $\begin{array}{c}97.145 \\
(.69)\end{array}$ & $\begin{array}{c}133.555 \\
(1.08)\end{array}$ & $\begin{array}{l}-4.4019 \\
(-.10)\end{array}$ & $\begin{array}{c}113.701 \\
(1.16)\end{array}$ & $\begin{array}{c}26.00223 \\
(0.73)\end{array}$ & $\begin{array}{l}-45.084 \\
(-1.19)\end{array}$ & $\begin{array}{l}-19.377 \\
(-0.60)\end{array}$ \\
\hline $\begin{array}{l}\text { Non Farm } \\
\text { Productivity } \\
\text { Hours }\end{array}$ & $\begin{array}{c}201.347 \\
(1.91)\end{array}$ & $\begin{array}{c}175.882 \\
(2.02)\end{array}$ & $\begin{array}{l}68.182 \\
(1.99)\end{array}$ & $\begin{array}{c}70.0496 \\
(0.90)\end{array}$ & $\begin{array}{l}52.720 \\
(1.90)\end{array}$ & $\begin{array}{l}25.734 \\
(0.85)\end{array}$ & $\begin{array}{l}10.529 \\
(0.40)\end{array}$ \\
\hline Constant & $\begin{array}{c}-5860.314 \\
(-1.38)\end{array}$ & $\begin{array}{c}-2120.428 \\
(-.61)\end{array}$ & $\begin{array}{c}-9725.22 \\
(-4.30)\end{array}$ & $\begin{array}{c}8996.791 \\
(1.53)\end{array}$ & $\begin{array}{c}-2918.688 \\
(-2.35)\end{array}$ & $\begin{array}{c}-1512.357 \\
(-0.64)\end{array}$ & $\begin{array}{c}3448.643 \\
(1.34)\end{array}$ \\
\hline Obs. & 49 & 49 & 49 & 49 & 49 & 49 & 49 \\
\hline Adj. R sq. & .965 & .964 & .932 & .589 & .858 & .448 & .310 \\
\hline DW-Stat & 1.690 & 1.718 & 1.903 & 1.0490 & 1.965 & 1.765 & 1.658 \\
\hline Rho & .608 & .333 & .868 & .882 & .771 & .885 & .904 \\
\hline
\end{tabular}

Notes: T-statistics are found in parentheses.

For a sample of size 50 and 8 explanatory variables, the critical values for the Durbin-Watson Statistic are: dl=1.2 and du=1.93 at the 5\% level (Savin and White 1977).

Source: See Appendix A. 
Next an analysis of the fields of study broken down by gender is conducted. Due to data availability, Tables 4 and 5, for males and females respectively, only show the number of PhDs in each field of study from 1964-2006 (41 observations). Research and development expenditures in the analysis for males is positive and statistically significant for all of the fields of study, while for women research and development expenditure are positive and significant for physical sciences and negatively statistically significant for education. A one standard deviation increase in the level of research and development expenditures results in a 4,348 increase in physical science PhDs for males and a 659 decrease in PhDs for females, while the same increase in research and development expenditures would result in a 399 increase in social science PhDs for males, a 292 increase in education PhDs for males and a 311 decrease for females, and a 652 increase in humanities $\mathrm{PhDs}$ for males. Again the coefficient on research and development expenditures is consistent with the hypothesis that following Sputnik a larger proportion of the Federal research and development expenditure funding went for the physical sciences and increased PhD production in this area. The negative effect for females may be due to their being crowded out by males entering the sciences.

During this time period, the military variables are a dichotomous variable for the Vietnam War and the level of military conscription. For men, the military variables are positive and statistically significant for all non-physical sciences fields, and are not statistically significant for the physical sciences. For women, the wartime variables are only positive and significant for the Vietnam War for both education and humanities PhDs. The Vietnam War effect resulted in a per year increase in social sciences $\mathrm{PhDs}$ for males by 679, an increase in education PhDs by 884 for males and 176 for females, and an increase in humanities PhDs for males by 458 and 273 for females. A one standard deviation increase in the conscription levels six years previously results 
in an increase in social science PhDs for males by 674, an increase in education PhDs for males by 798, and an increase in humanities PhDs for males by 582. Overall, we still see that the wartime variables have a larger effect for males.

The adult male unemployment rate is only statistically significant, and positive, for males in physical sciences, where a one standard deviation increase in the male unemployment rate results in a 393 increase in PhDs. During a recession the decrease in the opportunity cost of time apparently dominates the wealth effect for males in the physical sciences. For social sciences, education, and humanities the non-significant coefficient implies that there is no cyclical effect on the number of people getting these PhDs. This is consistent with the hypothesis that a smaller proportion of students in these fields will receive financial support, increasing the importance of negative income effect compared to the effect of the opportunity cost of time.

The nonfarm productivity variable is significantly positive in the social sciences and education for males and not statistically significant for females. A one standard deviation increase in the nonfarm productivity will increase social science PhDs for males by 1,476 and an increase in education PhDs for males by 1,960. These results suggest that for males an increase in productivity in the economy increases the value of getting a $\mathrm{PhD}$ in both social sciences and education, but not for males in the fields of physical sciences or humanities and not for females in any of the fields of study.

The time trends imply that other measured variables the same there is an increase in social science PhDs for men, but a decrease in the humanities. This may be the result of changing expectations of labor market outcomes in these fields. For both the physical sciences and education the time component is not significant suggesting that for these fields' changes in $\mathrm{PhD}$ production over time are fully explained by changes in the other explanatory variables. 
Using the Cochrane-Orcutt method, for men there is no time trend for $\mathrm{PhD}$ production in the physical sciences and a decline for education.

For women in the humanities, the social sciences, and education the significant positive time trends suggest that the production of $\mathrm{PhDs}$ has been increasing over time for unmeasured reasons. This could be due to market factors encouraging women into what used to be male dominated occupations requiring a degree in the physical sciences. On the other had, in the physical sciences, the non-significant time coefficient suggests that other variables are explaining in full the changes over time in $\mathrm{PhD}$ production. 
Table 4: Analysis of PhD Production for Males, by Statistical Method, United States, 1966-2006

\begin{tabular}{|c|c|c|c|c|c|c|c|c|}
\hline \multirow[b]{2}{*}{$\begin{array}{l}\text { Independent } \\
\text { Variables }\end{array}$} & \multicolumn{4}{|c|}{ OLS } & \multicolumn{4}{|c|}{ Cochrane-Orcutt } \\
\hline & $\begin{array}{c}\text { Physical } \\
\text { Science Total }\end{array}$ & $\begin{array}{c}\text { Social } \\
\text { Science } \\
\text { Total }\end{array}$ & $\begin{array}{l}\text { Education } \\
\text { Total }\end{array}$ & $\begin{array}{l}\text { Humanities } \\
\text { Total }\end{array}$ & $\begin{array}{c}\text { Physical } \\
\text { Science Total }\end{array}$ & $\begin{array}{c}\text { Social Science } \\
\text { Total }\end{array}$ & $\begin{array}{l}\text { Education } \\
\text { Total }\end{array}$ & $\begin{array}{c}\text { Humanities } \\
\text { Total }\end{array}$ \\
\hline $\begin{array}{l}\text { Research and } \\
\text { Development } \\
\text { (trillions \$) }\end{array}$ & $\begin{array}{c}187 \\
(8.97)\end{array}$ & $\begin{array}{c}17 \\
(3.35)\end{array}$ & $\begin{array}{c}13 \\
(1.97)\end{array}$ & $\begin{array}{c}28 \\
(5.75)\end{array}$ & $\begin{array}{c}98 \\
(3.66)\end{array}$ & $\begin{array}{c}13 \\
(1.79)\end{array}$ & $\begin{array}{c}15 \\
(1.86)\end{array}$ & $\begin{array}{c}20 \\
(2.67)\end{array}$ \\
\hline Vietnam & $\begin{array}{c}-350.079 \\
(-0.91)\end{array}$ & $\begin{array}{c}679.347 \\
(7.18)\end{array}$ & $\begin{array}{c}884.365 \\
(7.46)\end{array}$ & $\begin{array}{c}457.700 \\
(5.07)\end{array}$ & $\begin{array}{c}145.519 \\
(0.39)\end{array}$ & $\begin{array}{c}257.623 \\
(2.45)\end{array}$ & $\begin{array}{c}377.178 \\
(3.28)\end{array}$ & $\begin{array}{c}141.831 \\
(1.33)\end{array}$ \\
\hline $\begin{array}{c}\text { Conscription } \\
\text { (millions) }\end{array}$ & $\begin{array}{c}-80 \\
(-0.04)\end{array}$ & $\begin{array}{l}2560 \\
(4.84)\end{array}$ & $\begin{array}{c}3030 \\
(4.56)\end{array}$ & $\begin{array}{l}2210 \\
(4.38)\end{array}$ & $\begin{array}{l}1050 \\
(0.62)\end{array}$ & $\begin{array}{l}1050 \\
(2.19)\end{array}$ & $\begin{array}{c}790 \\
(1.52)\end{array}$ & $\begin{array}{c}680 \\
(1.39)\end{array}$ \\
\hline Year & $\begin{array}{c}-178.198 \\
(-1.35)\end{array}$ & $\begin{array}{c}126.857 \\
(3.91)\end{array}$ & $\begin{array}{l}-6.202 \\
(-0.15)\end{array}$ & $\begin{array}{l}-66.368 \\
(-2.14)\end{array}$ & $\begin{array}{c}-520.533 \\
(-1.09)\end{array}$ & $\begin{array}{c}-193.563 \\
(-1.88)\end{array}$ & $\begin{array}{c}-464.364 \\
(-3.68)\end{array}$ & $\begin{array}{c}-215.092 \\
(-2.90)\end{array}$ \\
\hline Year $^{2}$ & $\begin{array}{l}1.859 \\
(1.89)\end{array}$ & $\begin{array}{c}-3.252 \\
(-13.48)\end{array}$ & $\begin{array}{l}-2.396 \\
(-7.92)\end{array}$ & $\begin{array}{l}0.847 \\
(3.68)\end{array}$ & $\begin{array}{l}7.248 \\
(1.18)\end{array}$ & $\begin{array}{l}1.596 \\
(1.15)\end{array}$ & $\begin{array}{l}4.703 \\
(2.82)\end{array}$ & $\begin{array}{l}2.848 \\
(2.72)\end{array}$ \\
\hline $\begin{array}{l}\text { Male } \\
\text { Unemployment } \\
\text { Rate }\end{array}$ & $\begin{array}{c}287.407 \\
(2.36)\end{array}$ & $\begin{array}{l}-26.943 \\
(-0.90)\end{array}$ & $\begin{array}{l}-53.767 \\
(-1.43)\end{array}$ & $\begin{array}{l}-0.004 \\
(-0.00)\end{array}$ & $\begin{array}{c}83.888 \\
(0.87)\end{array}$ & $\begin{array}{l}11.435 \\
(0.42)\end{array}$ & $\begin{array}{l}-25.616 \\
(-0.87)\end{array}$ & $\begin{array}{l}-9.158 \\
(-0.33)\end{array}$ \\
\hline $\begin{array}{l}\text { Non Farm } \\
\text { Productivity } \\
\text { Hours }\end{array}$ & $\begin{array}{l}19.179 \\
(0.24)\end{array}$ & $\begin{array}{l}66.572 \\
(3.36)\end{array}$ & $\begin{array}{l}88.384 \\
(3.56)\end{array}$ & $\begin{array}{l}2.923 \\
(0.15)\end{array}$ & $\begin{array}{l}22.275 \\
(0.30)\end{array}$ & $\begin{array}{l}6.966 \\
(0.33)\end{array}$ & $\begin{array}{l}-12.865 \\
(-0.57)\end{array}$ & $\begin{array}{l}-10.647 \\
(-0.50)\end{array}$ \\
\hline Constant & $\begin{array}{c}1287.085 \\
(0.36)\end{array}$ & $\begin{array}{c}-2361.829 \\
(-2.73)\end{array}$ & $\begin{array}{c}-1784.864 \\
(-1.64)\end{array}$ & $\begin{array}{c}1660.359 \\
(2.01)\end{array}$ & $\begin{array}{c}12881.660 \\
(1.09)\end{array}$ & $\begin{array}{c}8108.776 \\
(3.15)\end{array}$ & $\begin{array}{c}14017.740 \\
(4.48)\end{array}$ & $\begin{array}{c}6154.433 \\
(3.12)\end{array}$ \\
\hline Obs. & 41 & 41 & 41 & 41 & 40 & 40 & 40 & 40 \\
\hline Adj. R sq. & .886 & .941 & .966 & .905 & .307 & .572 & .747 & .457 \\
\hline DW-Stat & 0.861 & 1.638 & 1.569 & 1.485 & 1.122 & 2.159 & 2.0689 & 1.979 \\
\hline Rho & & & & & .878 & .849 & .863 & .795 \\
\hline
\end{tabular}

Notes: T-statistics found in parentheses.

For a sample of size 40 and 8 explanatory variables, the critical values for the Durbin-Watson Statistic are: $\mathrm{dl}=1.064$ and du=1.997at the $5 \%$ level (Savin and White 1977).

Source: See Appendix A. 
Table 5: Analysis of PhD Production for Females, by Statistical Method, United States, 1966-2006

\begin{tabular}{|c|c|c|c|c|c|c|c|c|}
\hline \multirow[b]{2}{*}{$\begin{array}{l}\text { Independent } \\
\text { Variables }\end{array}$} & \multicolumn{4}{|c|}{ OLS } & \multicolumn{4}{|c|}{ Cochrane-Orcutt } \\
\hline & $\begin{array}{c}\text { Physical } \\
\text { Science Total }\end{array}$ & $\begin{array}{c}\text { Social Science } \\
\text { Total }\end{array}$ & Education Total & $\begin{array}{l}\text { Humanities } \\
\text { Total }\end{array}$ & $\begin{array}{c}\text { Physical } \\
\text { Science Total }\end{array}$ & $\begin{array}{c}\text { Social } \\
\text { Science Total }\end{array}$ & $\begin{array}{l}\text { Education } \\
\text { Total }\end{array}$ & $\begin{array}{c}\text { Humanities } \\
\text { Total }\end{array}$ \\
\hline $\begin{array}{l}\text { Research and } \\
\text { Development } \\
\text { (trillions \$) }\end{array}$ & $\begin{array}{c}28 \\
(3.97)\end{array}$ & $\begin{array}{c}7 \\
(1.69)\end{array}$ & $\begin{array}{c}-13 \\
(-3.31)\end{array}$ & $\begin{array}{c}8 \\
(1.68)\end{array}$ & $\begin{array}{c}11 \\
1.18\end{array}$ & $\begin{array}{c}7 \\
1.51\end{array}$ & $\begin{array}{l}-12 \\
-2.14\end{array}$ & $\begin{array}{c}6 \\
1.25\end{array}$ \\
\hline Vietnam & $\begin{array}{c}-150.124 \\
(-1.14)\end{array}$ & $\begin{array}{l}12.989 \\
(0.17)\end{array}$ & $\begin{array}{l}175.969 \\
(2.35)\end{array}$ & $\begin{array}{c}272.708 \\
(3.27)\end{array}$ & $\begin{array}{l}-21.754 \\
(-0.16)\end{array}$ & $\begin{array}{c}39.991 \\
(0.56)\end{array}$ & $\begin{array}{c}160.149 \\
(1.98)\end{array}$ & $\begin{array}{l}59.312 \\
(0.88)\end{array}$ \\
\hline $\begin{array}{l}\text { Conscription } \\
\text { (millions) }\end{array}$ & $\begin{array}{c}-500 \\
(-0.68)\end{array}$ & $\begin{array}{c}-520 \\
(-1.23)\end{array}$ & $\begin{array}{c}-750 \\
(-1.79)\end{array}$ & $\begin{array}{c}450 \\
(0.96)\end{array}$ & $\begin{array}{c}-60 \\
(-0.09)\end{array}$ & $\begin{array}{c}-110 \\
(-0.32)\end{array}$ & $\begin{array}{l}-120 \\
(-0.32)\end{array}$ & $\begin{array}{l}160 \\
(0.51)\end{array}$ \\
\hline Year & $\begin{array}{l}-68.376 \\
(-1.51)\end{array}$ & $\begin{array}{c}168.042 \\
(6.49)\end{array}$ & $\begin{array}{c}297.815 \\
(11.61)\end{array}$ & $\begin{array}{l}60.769 \\
(2.12)\end{array}$ & $\begin{array}{c}-73.019 \\
(-0.82)\end{array}$ & $\begin{array}{c}196.320 \\
(7.07)\end{array}$ & $\begin{array}{c}342.802 \\
(9.03)\end{array}$ & $\begin{array}{l}31.430 \\
(0.36)\end{array}$ \\
\hline Year $^{2}$ & $\begin{array}{l}2.826 \\
(8.39)\end{array}$ & $\begin{array}{l}-1.120 \\
(-5.82)\end{array}$ & $\begin{array}{c}-3.490 \\
(-18.30)\end{array}$ & $\begin{array}{l}0.107 \\
(0.50)\end{array}$ & $\begin{array}{l}2.948 \\
(2.33)\end{array}$ & $\begin{array}{l}-1.604 \\
(-4.48)\end{array}$ & $\begin{array}{l}-3.916 \\
(-7.35)\end{array}$ & $\begin{array}{l}0.094 \\
(0.08)\end{array}$ \\
\hline $\begin{array}{c}\text { Male } \\
\text { Unemployment } \\
\text { Rate }\end{array}$ & $\begin{array}{l}64.368 \\
(1.54)\end{array}$ & $\begin{array}{l}22.692 \\
(0.95)\end{array}$ & $\begin{array}{c}-43.688 \\
(-1.85)\end{array}$ & $\begin{array}{l}-31.809 \\
(-1.21)\end{array}$ & $\begin{array}{l}33.474 \\
(0.95)\end{array}$ & $\begin{array}{l}21.570 \\
(1.07)\end{array}$ & $\begin{array}{l}-26.602 \\
(-1.22)\end{array}$ & $\begin{array}{l}-22.824 \\
(-1.32)\end{array}$ \\
\hline $\begin{array}{l}\text { Non Farm } \\
\text { Productivity Hours }\end{array}$ & $\begin{array}{l}29.345 \\
(1.06)\end{array}$ & $\begin{array}{l}11.419 \\
(0.72)\end{array}$ & $\begin{array}{l}22.251 \\
(1.42)\end{array}$ & $\begin{array}{l}-5.369 \\
(-0.31)\end{array}$ & $\begin{array}{c}45.022 \\
(1.67)\end{array}$ & $\begin{array}{l}18.656 \\
(1.28)\end{array}$ & $\begin{array}{l}12.439 \\
(0.76)\end{array}$ & $\begin{array}{l}6.162 \\
(0.46)\end{array}$ \\
\hline Constant & $\begin{array}{c}-2097.786 \\
(-1.74)\end{array}$ & $\begin{array}{c}-2651.215 \\
(-3.84)\end{array}$ & $\begin{array}{c}-3144.230 \\
(-4.60)\end{array}$ & $\begin{array}{c}-274.263 \\
(-0.36)\end{array}$ & $\begin{array}{c}-2252.140 \\
(-0.94)\end{array}$ & $\begin{array}{c}-3670.312 \\
(-4.23)\end{array}$ & $\begin{array}{c}-3502.017 \\
(-3.10)\end{array}$ & $\begin{array}{c}-31.589 \\
(-0.01)\end{array}$ \\
\hline Obs. & 41 & 41 & 41 & 41 & 40 & 40 & 40 & 40 \\
\hline Adj. R sq. & 0.990 & 0.992 & 0.988 & 0.960 & 0.914 & 0.973 & 0.891 & 0.362 \\
\hline DW-Stat & 0.780 & 0.781 & 0.925 & 0.560 & 1.476 & 2.253 & 1.649 & 1.717 \\
\hline Rho & & & & & 0.784 & 0.577 & 0.690 & 0.880 \\
\hline
\end{tabular}

Notes: T-statistics found in parentheses.

For a sample of size 40 and 8 explanatory variables, the critical values for the Durbin-Watson Statistic are: $\mathrm{dl}=1.064$ and du=1.997at the 5\% level (Savin and White 1977).

Source: See Appendix A. 
(B) Canada

Table 6 presents the ordinary least squares regressions for the production of PhDs in Canada. Due to data limitations there are only 37 observations for Canada from 1968 to 2005. The Canadian results are consistent with the patterns for the U.S.

Similar to the United States results, Canadian research and development expenditures is statistically significant and positive for the total, male, and female PhDs. This result is consistent with the hypothesis that increases in research and development expenditure will increase the available funding for people earning their PhDs. One difference between the US and Canada is that the coefficient for females is statistically significant in Canada.

US military related variables are entered into the Canadian equation. The Vietnam War variable is statistically significant and negative for the total PhDs, but not significant for either males or females separately. The United States military conscription variable is not significant for any of the Canadian results. This is consistent with the hypothesis that since there was no military conscription during this time in Canada, the US values should have no effect on Canadian PhD production. This supports the hypothesis that these variables for the US are measuring the military effect and are not proxies for unmeasured variables that might have similar effects in the US and Canada.

The Canadian male unemployment rate is statistically positive for both males and females. The positive coefficient suggests that a decrease in the opportunity cost of time has a larger impact than the negative income effect. This may arise from a muted income effect since most students receiving a Canadian $\mathrm{PhD}$ do not pay tuition or fees.

The Canadian productivity variable is statistically significant and negative for both the total and for females, while being statistically insignificant for males. This is different than the 
positive results for the United States. For females in Canada the increase in productivity will lead to a decrease in $\mathrm{PhD}$ production. The result could suggest that for females when there is an increase in productivity, suggesting a growth in the economy, they will enter into occupations that do not need a PhD. This is not the case for males in Canada; the insignificance of the productivity variable suggests that changes in productivity will have no effect on $\mathrm{PhD}$ production for males.

For Canadian PhDs, the time variables show that, other variables being the same, total $\mathrm{PhD}$ production in Canada is increasing, but at a decreasing rate. Analyzing the genders separately shows that neither the time trend nor its square is statistically significant for males. This suggests that the changes in the number of males getting a $\mathrm{PhD}$ each year are due to the other explanatory variables. While for females the time trend is statistically significant and positive and the time trend square is not statistically different from zero. This implies that females $\mathrm{PhD}$ production, ceteris paribus, in this period was increasing at a constant rate of about $30 \mathrm{PhDs}$ a year. 
Table 6: Ordinary Least Squares:

Analysis of PhD Production, Canada, 1968-2005

\begin{tabular}{|c|c|c|c|}
\hline \multirow{3}{*}{$\begin{array}{l}\text { Independent } \\
\text { Variables }\end{array}$} & \multicolumn{3}{|c|}{ Dependent Variables } \\
\hline & \multirow[b]{2}{*}{ Total } & \multicolumn{2}{|c|}{ Gender } \\
\hline & & Male & Female \\
\hline $\begin{array}{l}\text { Research and } \\
\text { Development } \\
\text { (trillions \$) }\end{array}$ & $\begin{array}{c}278 \\
(3.63)\end{array}$ & $\begin{array}{c}324 \\
(2.54)\end{array}$ & $\begin{array}{c}46 \\
(2.5)\end{array}$ \\
\hline Vietnam & $\begin{array}{c}-186.808 \\
(-1.93)\end{array}$ & $\begin{array}{c}-186.148 \\
(-1.46)\end{array}$ & $\begin{array}{l}1.464 \\
(.06)\end{array}$ \\
\hline $\begin{array}{l}\text { Induction } \\
\text { (millions) }\end{array}$ & $\begin{array}{l}-130 \\
(-.24)\end{array}$ & $\begin{array}{l}-130 \\
(1.26)\end{array}$ & $\begin{array}{c}0 \\
(.02)\end{array}$ \\
\hline Year & $\begin{array}{c}302.332 \\
(5.92)\end{array}$ & $\begin{array}{c}332.521 \\
(.72)\end{array}$ & $\begin{array}{c}30.555 \\
(2.5)\end{array}$ \\
\hline Year $^{2}$ & $\begin{array}{l}-3.903 \\
(-5.26)\end{array}$ & $\begin{array}{l}-3.704 \\
(-1.08)\end{array}$ & $\begin{array}{l}0.201 \\
(1.14)\end{array}$ \\
\hline $\begin{array}{l}\text { Male Unemployment } \\
\text { Rate }\end{array}$ & $\begin{array}{c}13.283 \\
(.68)\end{array}$ & $\begin{array}{l}29.390 \\
(2.04)\end{array}$ & $\begin{array}{l}16.314 \\
(3.50)\end{array}$ \\
\hline $\begin{array}{c}\text { Non Farm } \\
\text { Productivity Hours }\end{array}$ & $\begin{array}{c}-310.758 \\
(-5.12)\end{array}$ & $\begin{array}{c}-348.580 \\
(-1.63)\end{array}$ & $\begin{array}{l}-38.512 \\
(-2.66)\end{array}$ \\
\hline Constant & $\begin{array}{l}1607.908 \\
(2.83)\end{array}$ & $\begin{array}{c}1585.824 \\
-0.18\end{array}$ & $\begin{array}{c}-16.467 \\
(-.12)\end{array}$ \\
\hline Obs. & 37 & 37 & 37 \\
\hline Adj. R sq. & 0.885 & 0.972 & 0.996 \\
\hline DW-Stat & 1.082 & 1.195 & 1.994 \\
\hline
\end{tabular}

Notes: T-statistics found in parentheses.

For a sample of size 37 and 8 explanatory variables, the critical values for the Durbin-Watson Statistic are: dl=1.011 and $d u=2.029$ the $5 \%$ level (Savin and White 1977).

Source: See Appendix A. 


\section{Summary and Conclusion}

This paper has analyzed the determinants of the production of PhDs in the United States and Canada in the post-World War II period. The empirical analysis for the US (1950-2006) overall, by gender, and by major discipline, and for Canada (1968-2005) overall and by gender are generally consistent with the hypothesis derived from the model.

The production of male PhDs in the U.S. was substantially increased by U.S. military conscription with educational exemptions, and the Vietnam War. As expected, there was apparently no separate effect of the brief Korean War, on female PhD production, or on $\mathrm{PhD}$ output in Canada. In both the U.S. and Canada government expenditures on research and development increased overall and male PhD production (and in Canada female PhDs as well). The effect is strongest in the Physical Sciences and weakest in Education reflecting where the funds were spent. The rate of growth of non-farm productivity generally has had a positive effect encouraging PhD productivity overall and for males in the U.S., perhaps suggesting it raises the economic returns to receiving a PhD, but has no effect for females. In Canada, on the other hand, the growth rate of productivity has a negative effect on $\mathrm{PhD}$ output. The cyclical indicator, the adult male unemployment rate, has a weak positive effect for males in the U.S. and Canada, suggesting that the positive effect of the reduced opportunity cost of time outweighs the negative wealth or income effect of a recession. Among women, however, the unemployment rate has no effect in the U.S., but a strong positive effect in Canada.

There has been an increase over time in both countries in the female receipt of the $\mathrm{PhD}$ over and above the effect of the other variables in the analysis. There has been no such increase for males. As a result, there has been a narrowing in the $\mathrm{PhD}$ gender gap. This may reflect the effects of the increased female attachment to the labor market, increasing the attractiveness for 
women of the large investment in the $\mathrm{PhD}$, and perhaps decreased discrimination against women $\mathrm{PhD}$ candidates in higher education and PhD holders in the labor market and the marriage market.

The analysis has implications for increasing PhD production in the U.S. and Canada. Clearly one would not advocate war or the reinstatement of military conscription to accomplish this objective. Nor would one advocate a higher unemployment rate (a recession) to encourage $\mathrm{PhD}$ enrollment. Higher rates of productivity growth in the economy are desirable, but have a mixed picture in terms of $\mathrm{PhD}$ production. Higher rates of government expenditure on research and development have the effect of increasing $\mathrm{PhD}$ production in the U.S. and Canada. In the U.S. the effect has been greatest among men and in the physical sciences, but this may because the funds have been largely targeted to the physical sciences, which is the most male intensive of the four major disciplines in the data.

Finally, continued increases in female labor force participation through increased attachment among those participating in the labor force and continued reductions in discrimination in higher education, in the labor market and in the marriage market against women who obtain a $\mathrm{PhD}$ would increase their numbers and reduce the $\mathrm{PhD}$ gender gap. 
"The Production of PhDs in the United States and Canada"

Statistical Appendix:

Appendix A:

This appendix contains data on the awarding of PhDs by Universities in the United States (1950-2006) and Canada (1968-2005). The data are from the NSF Survey of Earned

Doctorates/Doctorate Records File for years 1966-2006 (Web address: http://webcaspar.nsf.gov/) and from U.S. Department of Commerce, Historical Statistics of the United States, Colonial Times to 1970 House document-93 ${ }^{\text {rd }}$ Congress, $1^{\text {st }}$ session; no 93-78. Bureau of the Census Series H 751-765 Institutions of Higher Education-Degrees Conferred, by Sex: 1870 to 1970 for the years 1950-1966.

The data are reported separately by the four major subject divisions (Physical Science, Social Science, Humanities, and Education) and in total. Within each of these subject divisions the data are further separated by gender, minority group status, and citizenship.

The four major subject divisions are:

Physical Science: Engineering, Physical Science, Geosciences, Math and Computer Science, Life Sciences, and Architecture and Environmental Design.

Humanities: Humanities, Religion and Theology, Arts and Music, Communication and Librarianship, and Law.

Social Science: Social Science, Business and Management, Social Service Professions, Psychology.

Education: Education, Vocational Studies and Home Economics.

Data on PhDs awarded by Canadian Universities are taken from Table W504-512 (Website address: http://www.statcan.gc.ca/pub/ 11-516-x/sectionw/4147445-eng. htm) for years 
1955-1973, from table 477-0014 available through CANSIM (Website address:

http://cansim2.statcan.gc.ca/ cgi-win/CNSMCGI.EXE?LANG=Eng\& Dir-Rep=CII/\&CNSM-

Fi=CII/CII_ 1-eng.htm) for years 1970-1997, and from CANSIM (Website address:

http://library.queensu.ca/webdoc/ssdc/xcleduc99.htm\#top) for years 1992-2005. Canadian PhDs are reported by gender and total.

Appendix Table A contains the definition of the variables, data sources, and the descriptive statistics of variables. Appendix B contains the number of PhDs awarded by year for the U.S. overall, by gender, and by major discipline and for Canada overall and by gender. Appendix B is available upon request. 


\section{Table A:}

Definition of Variables, Data Sources, and Descriptive Statistics of Variables

Dependent Variables:

1. Total number of Ph.D.s awarded in the U.S (by gender, by discipline, by minority status and in total)

- U.S. Department of Commerce, Historical Statistics of the United States, Colonial Times to 1970 House document-93 ${ }^{\text {rd }}$ Congress, $1^{\text {st }}$ session; no 93-78. Bureau of the Census Series H 751-765 Institutions of Higher EducationDegrees Conferred, by Sex: 1870 to 1970 for the years 1950-1966.

- $\quad$ NSF Survey of Earned Doctorates/Doctorate Records File for years 19662006 (Web address: http://webcaspar.nsf.gov/).

2. Total number of Ph.D.s awarded in Canada (by gender and in total)

a. Table W504-512 (Website address: http://www.statcan.gc.ca/pub/ 11-516x/sectionw/4147445-eng. htm) for years 1955-1973.

b. Table 477-0014 available through CANSIM (Website address: http://cansim2. statcan.gc.ca/ cgi-win/CNSMCGI.EXE?LANG=Eng\& Dir-Rep=CII/\&CNSM-

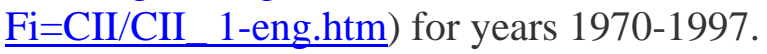

c. CANSIM (Website address: http://library.queensu.ca/webdoc/ssdc/ xcleduc99.htm\#top) for years 1992-2005.

Explanatory Variables:

United States:

1. Time trend (1954-2006, 1-53) and square of time trend

2. Unemployment rate $\left(\mathrm{UR}_{\mathrm{t}-6}\right)$

- Adult (over 25) male annual unemployment rate.

- Statistics are from the Bureau of Labor Statistics (Website address: http://data.bls.gov).

3. Total Federal Government $\mathrm{R} \& \mathrm{D}$ spending $\left(\mathrm{RnD}_{\mathrm{t}-6}\right)$ 
- NSF Survey of Federal Funds for Research and Development 1951-2006.

4. Indicator of Korea War and Vietnam War

- Korean War = 1 from 1950-1953; 0 otherwise.

- Vietnam War = 1 from 1964-1975; 0 otherwise.

- Statistics are from Selective Services System (Website address: http://www.sss.gov/induct.htm).

5. Number of military induction

- Number of men conscripted annually.

- Statistics are from Selective Services System (Website address: http://www.sss.gov/induct.htm).

6. Productivity and productivity growth

- Productivity measured as output/worker.

- Productivity growth is percent change in productivity.

- Statistics are from the Bureau of Labor Statistics (Website address: http://data.bls.gov).

Canada:

1. Time trend (1969-2006, 1-37) and square of time trend

2. Unemployment rate $\left(\mathrm{UR}_{\mathrm{t}-6}\right)$

- Adult (over 25) male annual unemployment rate.

- Statistics are from StatCan: Table 282-0002 (Website address: www.statcan.gc.ca).

3. Total Federal Government $\mathrm{R} \& \mathrm{D}$ spending $\left(\mathrm{RnD}_{\mathrm{t}-6}\right)$

- Gross domestic expenditures, research/development all sectors 1997 dollars.

- Statistics are from StatCan: Table 358-0001 (Website address: www.statcan.gc.ca).

4. Indicator of Vietnam War

- Vietnam War = 1 from 1964-1975; 0 otherwise.

- Statistics are from Selective Services System (Website address: http://www.sss.gov/induct.htm).

5. Number of military induction for US.

- Number of men conscripted annually. 
- Statistics are from Selective Services System (Website address: http://www.sss.gov/induct.htm).

6. Productivity and productivity growth

a. Productivity measured as output/worker.

b. Statistics are from the StatCan: Table 383-0003 (Website address: www.statcan.gc.ca). 
Table A-1:

Summary Statistics of Dependent and

Explanatory Variables, United States \&

Canada

\begin{tabular}{|c|c|c|c|c|c|}
\hline Dependent Variable & Obs & Mean & Std. Dev. & Min & $\operatorname{Max}$ \\
\hline \multicolumn{6}{|l|}{ U.S. } \\
\hline \multicolumn{6}{|l|}{ Gender } \\
\hline Male & 57 & 19128.19 & 6860.608 & 5990 & 27754 \\
\hline Female & 57 & 8635.281 & 6640.122 & 643 & 20539 \\
\hline \multicolumn{6}{|l|}{ Field } \\
\hline Physical Science & 57 & 12726.3 & 6137.691 & 3122 & 24314 \\
\hline Social Science & 57 & 6014.93 & 2858.339 & 1250 & 9160 \\
\hline Humanities & 57 & 3747.263 & 1692.341 & 879 & 5859 \\
\hline Education & 57 & 5159.702 & 2407.358 & 834 & 7793 \\
\hline \multicolumn{6}{|l|}{ Field and Gender } \\
\hline 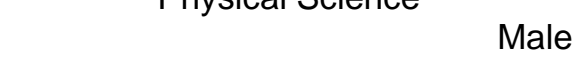 & 41 & 12285.32 & 1931.995 & 8488 & 15763 \\
\hline Female & 41 & 3537.415 & 2284.184 & 531 & 8508 \\
\hline \multicolumn{6}{|l|}{ Social Science } \\
\hline Male & 41 & 4619.854 & 661.2412 & 2708 & 5785 \\
\hline \multirow{2}{*}{\multicolumn{6}{|c|}{ Humanities }} \\
\hline & & & & & \\
\hline Male & 41 & 2797.146 & 495.5761 & 2150 & 4080 \\
\hline \multirow{2}{*}{\multicolumn{6}{|c|}{ Education }} \\
\hline & & & & & \\
\hline Male & 41 & 3338.293 & 1082.995 & 2075 & 5461 \\
\hline Female & 41 & 3199.268 & 1168.084 & 620 & 4407 \\
\hline \multicolumn{6}{|l|}{ Canada } \\
\hline Total & 48 & 1552.292 & 699.5792 & 254 & 2595 \\
\hline Male & 48 & 2210.208 & 1237.401 & 281 & 4200 \\
\hline Female & 48 & 657.9167 & 580.1963 & 22 & 1848 \\
\hline \multicolumn{6}{|c|}{ Explanatory Variable Lagged Six Years } \\
\hline \multicolumn{6}{|l|}{ U.S. } \\
\hline Research and Development & 57 & $5.94 \mathrm{E}+07$ & $2.32 \mathrm{E}+07$ & 8835813 & $9.88 \mathrm{E}+07$ \\
\hline Vietnam War & 57 & 0.210526 & 0.411306 & 0 & 1 \\
\hline Korean War & 60 & 499.65 & 303.7646 & 0 & 1 \\
\hline Conscription & 57 & 133354.1 & 263386.2 & 0 & 1591942 \\
\hline Year & 53 & 27 & 15.44345 & 1 & 53 \\
\hline Year Squared & 53 & 963 & 860.2706 & 1 & 2809 \\
\hline Male Unemployment Rate & 53 & 4.016509 & 1.367848 & 1.675 & 7.725 \\
\hline Non-Farm Productivity Hours & 53 & 2.196226 & 1.56069 & -1.5 & 6.7 \\
\hline \multicolumn{6}{|l|}{ Canada } \\
\hline Research and Development & 44 & 9801.841 & 5916.655 & 2636 & 21661 \\
\hline Male Unemployment Rate & 46 & 6.223913 & 1.958478 & 2.9 & 10.4 \\
\hline Non-Farm Productivity Hours & 37 & 1.686887 & 1.749221 & -1.53846 & 5.780347 \\
\hline
\end{tabular}




\section{Appendix B:}

\section{Number of PhDs Awarded by Year}

Table B-1:

PhDs Awarded by U.S. Universities in Total and by

Gender, Discipline, and Year, 1950 to 2006

\begin{tabular}{|c|c|c|c|c|c|c|c|}
\hline Year & Total & Male & Female & $\begin{array}{l}\text { Physical } \\
\text { Science }\end{array}$ & $\begin{array}{c}\text { Social } \\
\text { Science }\end{array}$ & Humanities & Education \\
\hline 1950 & 6633 & 5990 & 643 & 3358 & 1250 & 879 & 1032 \\
\hline 1951 & 7337 & 6663 & 674 & 3678 & 1536 & 1004 & 1113 \\
\hline 1952 & 7683 & 6969 & 714 & 3862 & 1564 & 976 & 1314 \\
\hline 1953 & 8307 & 7515 & 792 & 3185 & 1752 & 1114 & 1425 \\
\hline 1954 & 8996 & 8181 & 815 & 4165 & 1865 & 1167 & 1509 \\
\hline 1955 & 8840 & 8014 & 826 & 4242 & 1938 & 1152 & 1572 \\
\hline 1956 & 8903 & 8018 & 885 & 3946 & 1765 & 1153 & 1636 \\
\hline 1957 & 8756 & 7817 & 939 & 3122 & 1299 & 929 & 834 \\
\hline 1958 & 8942 & 7978 & 964 & 4141 & 1885 & 1255 & 1491 \\
\hline 1959 & 9360 & 8371 & 989 & 4370 & 1974 & 1314 & 1553 \\
\hline 1960 & 9829 & 8801 & 1028 & 4673 & 2032 & 1472 & 1549 \\
\hline 1961 & 10575 & 9463 & 1112 & 5048 & 2153 & 1528 & 1679 \\
\hline 1962 & 11622 & 10377 & 1245 & 5676 & 2256 & 1668 & 1899 \\
\hline 1963 & 12822 & 11448 & 1374 & 6349 & 2417 & 1814 & 2132 \\
\hline 1964 & 14490 & 12955 & 1535 & 7141 & 2786 & 2027 & 2351 \\
\hline 1965 & 16467 & 14692 & 1775 & 8377 & 2934 & 2357 & 2736 \\
\hline 1966 & 17949 & 15863 & 2086 & 9019 & 3160 & 2665 & 3082 \\
\hline 1967 & 20403 & 17961 & 2442 & 10084 & 3698 & 3075 & 3521 \\
\hline 1968 & 22937 & 20005 & 2932 & 11219 & 4138 & 3459 & 4082 \\
\hline 1969 & 25743 & 22355 & 3388 & 12382 & 4805 & 3743 & 4708 \\
\hline 1970 & 29498 & 25527 & 3971 & 13641 & 5498 & 4249 & 5907 \\
\hline 1971 & 31867 & 27271 & 4596 & 14335 & 6382 & 4537 & 6479 \\
\hline 1972 & 33041 & 27754 & 5287 & 13962 & 6725 & 5113 & 7118 \\
\hline 1973 & 33755 & 27670 & 6085 & 13664 & 7094 & 5622 & 7287 \\
\hline 1974 & 33047 & 26594 & 6453 & 12903 & 7196 & 5517 & 7284 \\
\hline 1975 & 32952 & 25751 & 7201 & 12723 & 7459 & 5260 & 7402 \\
\hline 1976 & 32946 & 25262 & 7684 & 12207 & 7663 & 5148 & 7793 \\
\hline
\end{tabular}




\begin{tabular}{|c|c|c|c|c|c|c|c|}
\hline 1977 & 31716 & 23858 & 7858 & 11799 & 7558 & 4784 & 7531 \\
\hline 1978 & 30875 & 22553 & 8322 & 11497 & 7554 & 4515 & 7275 \\
\hline 1979 & 31238 & 22301 & 8937 & 11858 & 7451 & 4406 & 7472 \\
\hline 1980 & 31019 & 21612 & 9407 & 11891 & 7289 & 4113 & 7676 \\
\hline 1981 & 31355 & 21463 & 9892 & 12140 & 7611 & 3965 & 7582 \\
\hline 1982 & 31108 & 21015 & 10093 & 12467 & 7395 & 3839 & 7349 \\
\hline 1983 & 31280 & 20748 & 10532 & 12635 & 7612 & 3741 & 7253 \\
\hline 1984 & 31334 & 20636 & 10698 & 12988 & 7604 & 3804 & 6915 \\
\hline 1985 & 31295 & 20552 & 10743 & 13365 & 7343 & 3721 & 6823 \\
\hline 1986 & 31897 & 20592 & 11305 & 13781 & 7586 & 3737 & 6737 \\
\hline 1987 & 32365 & 20934 & 11431 & 14389 & 7531 & 3808 & 6520 \\
\hline 1988 & 33497 & 21677 & 11819 & 15533 & 7584 & 3862 & 6419 \\
\hline 1989 & 34325 & 21812 & 12513 & 16217 & 7806 & 3866 & 6335 \\
\hline 1990 & 36065 & 22960 & 13104 & 17252 & 7896 & 4205 & 6584 \\
\hline 1991 & 37530 & 23521 & 13873 & 18322 & 8209 & 4400 & 6484 \\
\hline 1992 & 38886 & 24232 & 14435 & 18973 & 8368 & 4727 & 6735 \\
\hline 1993 & 39800 & 24384 & 15121 & 19505 & 8708 & 4754 & 6749 \\
\hline 1994 & 41033 & 25057 & 15822 & 20285 & 8836 & 5080 & 6743 \\
\hline 1995 & 41747 & 25160 & 16416 & 20612 & 8943 & 5430 & 6681 \\
\hline 1996 & 42437 & 25285 & 16955 & 21128 & 9034 & 5386 & 6814 \\
\hline 1997 & 42539 & 24939 & 17243 & 21049 & 9160 & 5613 & 6621 \\
\hline 1998 & 42637 & 24628 & 17848 & 21096 & 9140 & 5713 & 6588 \\
\hline 1999 & 41097 & 23436 & 17484 & 19672 & 9066 & 5652 & 6575 \\
\hline 2000 & 41365 & 23163 & 18129 & 19847 & 9098 & 5859 & 6461 \\
\hline 2001 & 40737 & 22775 & 17885 & 19654 & 8807 & 5816 & 6371 \\
\hline 2002 & 40025 & 21805 & 18135 & 19108 & 8573 & 5703 & 6527 \\
\hline 2003 & 40757 & 22257 & 18500 & 19568 & 8725 & 5703 & 6664 \\
\hline 2004 & 42123 & 22963 & 19158 & 20596 & 9023 & 5692 & 6679 \\
\hline 2005 & 43385 & 23738 & 19579 & 22386 & 8959 & 5655 & 6277 \\
\hline 2006 & 45596 & 24986 & 20539 & 24314 & 9158 & 5848 & 6175 \\
\hline
\end{tabular}

Sources:

(a) NSF Survey of Earned Doctorates/Doctorate Records File for years 1966-2006 (Web address: http://webcaspar.nsf.gov/)

(b) U.S. Department of Commerce, Historical Statistics of the United States, Colonial Times to 1970 House document-93 ${ }^{\text {rd }}$ Congress, $1^{\text {st }}$ session; no 93-78. Bureau of the Census Series H 751-765 Institutions of Higher Education-Degrees Conferred, by Sex: 1870 to 1970 for the years 1950-1966 
Table B-2:

PhDs Awarded by U.S. Universities by Discipline, Gender and Year, 1966 to 2006

\begin{tabular}{|c|c|c|c|c|c|c|c|c|}
\hline \multirow[b]{2}{*}{ Year } & \multicolumn{2}{|c|}{ Physical Science } & \multicolumn{2}{|c|}{ Social Science } & \multicolumn{2}{|c|}{ Humanities } & \multicolumn{2}{|c|}{ Education } \\
\hline & Male & Female & Male & Female & Male & Female & Male & Female \\
\hline 1966 & 8488 & 531 & 2708 & 452 & 2182 & 483 & 2462 & 620 \\
\hline 1967 & 9448 & 636 & 3185 & 513 & 2516 & 559 & 2793 & 728 \\
\hline 1968 & 10464 & 755 & 3519 & 619 & 2750 & 709 & 3234 & 848 \\
\hline 1969 & 11528 & 854 & 4063 & 742 & 2914 & 829 & 3755 & 953 \\
\hline 1970 & 12697 & 944 & 4683 & 815 & 3284 & 965 & 4675 & 1232 \\
\hline 1971 & 13216 & 1119 & 5347 & 1035 & 3496 & 1041 & 5094 & 1385 \\
\hline 1972 & 12803 & 1159 & 5581 & 1144 & 3816 & 1297 & 5442 & 1676 \\
\hline 1973 & 12320 & 1344 & 5734 & 1360 & 4080 & 1542 & 5461 & 1826 \\
\hline 1974 & 11585 & 1318 & 5651 & 1545 & 3926 & 1591 & 5309 & 1975 \\
\hline 1975 & 11276 & 1447 & 5766 & 1693 & 3559 & 1701 & 5072 & 2330 \\
\hline 1976 & 10724 & 1483 & 5785 & 1878 & 3461 & 1687 & 5193 & 2600 \\
\hline 1977 & 10273 & 1526 & 5559 & 1999 & 3113 & 1671 & 4883 & 2648 \\
\hline 1978 & 9851 & 1646 & 5413 & 2141 & 2918 & 1597 & 4348 & 2927 \\
\hline 1979 & 10040 & 1818 & 5135 & 2316 & 2801 & 1605 & 4289 & 3183 \\
\hline 1980 & 9897 & 1994 & 4896 & 2393 & 2564 & 1549 & 4216 & 3460 \\
\hline 1981 & 10016 & 2124 & 5030 & 2581 & 2399 & 1566 & 3972 & 3610 \\
\hline 1982 & 10151 & 2316 & 4803 & 2592 & 2291 & 1548 & 3726 & 3623 \\
\hline 1983 & 10186 & 2449 & 4769 & 2843 & 2204 & 1537 & 3565 & 3688 \\
\hline 1984 & 10413 & 2575 & 4659 & 2945 & 2194 & 1610 & 3358 & 3557 \\
\hline 1985 & 10592 & 2773 & 4490 & 2853 & 2190 & 1531 & 3255 & 3568 \\
\hline 1986 & 10847 & 2934 & 4510 & 3076 & 2150 & 1587 & 3051 & 3686 \\
\hline 1987 & 11305 & 3084 & 4474 & 3057 & 2187 & 1621 & 2903 & 3617 \\
\hline 1988 & 12122 & 3411 & 4387 & 3196 & 2255 & 1607 & 2856 & 3563 \\
\hline 1989 & 12402 & 3815 & 4462 & 3344 & 2209 & 1657 & 2677 & 3658 \\
\hline 1990 & 13300 & 3952 & 4449 & 3447 & 2377 & 1828 & 2770 & 3813 \\
\hline 1991 & 13920 & 4310 & 4414 & 3770 & 2433 & 1959 & 2698 & 3775 \\
\hline 1992 & 14242 & 4584 & 4641 & 3684 & 2609 & 2102 & 2697 & 4025 \\
\hline 1993 & 14379 & 4932 & 4634 & 4022 & 2563 & 2165 & 2755 & 3971 \\
\hline 1994 & 14949 & 5237 & 4703 & 4100 & 2739 & 2329 & 2614 & 4119 \\
\hline 1995 & 14998 & 5501 & 4676 & 4231 & 2892 & 2528 & 2550 & 4119 \\
\hline
\end{tabular}




\begin{tabular}{|l|l|l|l|l|l|l|l|l|}
1996 & 15269 & 5733 & 4650 & 4352 & 2741 & 2626 & 2581 & 4213 \\
\hline 1997 & 14952 & 5936 & 4578 & 4494 & 2952 & 2621 & 2399 & 4154 \\
\hline 1998 & 14771 & 6232 & 4424 & 4676 & 2948 & 2755 & 2426 & 4144 \\
\hline 1999 & 13719 & 5856 & 4377 & 4654 & 2931 & 2693 & 2343 & 4215 \\
\hline 2000 & 13511 & 6288 & 4364 & 4718 & 2969 & 2886 & 2256 & 4200 \\
\hline 2001 & 13316 & 6294 & 4226 & 4566 & 2940 & 2866 & 2249 & 4114 \\
\hline 2002 & 12673 & 6400 & 4041 & 4509 & 2835 & 2854 & 2198 & 4316 \\
\hline 2003 & 13010 & 6558 & 4098 & 4627 & 2843 & 2860 & 2257 & 4407 \\
\hline 2004 & 13603 & 6992 & 4274 & 4749 & 2746 & 2946 & 2272 & 4406 \\
\hline 2005 & 14679 & 7666 & 4129 & 4821 & 2801 & 2847 & 2075 & 4192 \\
\hline 2006 & 15763 & 8508 & 4127 & 5016 & 2905 & 2938 & 2141 & 4026 \\
\hline
\end{tabular}

Sources:

NSF Survey of Earned Doctorates/Doctorate Records File for years 1966-2006 (Web address: http://webcaspar.nsf.gov/) 
Table B-3:

PhDs Awarded by Canadian Universities in Total, by Gender and Year, 1958 to 2005

\begin{tabular}{|c|c|c|c|}
\hline \multirow{2}{*}{} & \multicolumn{3}{|c|}{ Canada } \\
\cline { 2 - 4 } & & & \\
Year & Total & Male & Female \\
\hline 1958 & 254 & 284 & 30 \\
\hline 1959 & 259 & 281 & 22 \\
\hline 1960 & 279 & 306 & 27 \\
\hline 1961 & 295 & 321 & 26 \\
\hline 1962 & 387 & 421 & 34 \\
\hline 1963 & 443 & 481 & 38 \\
\hline 1964 & 512 & 566 & 54 \\
\hline 1965 & 619 & 696 & 77 \\
\hline 1966 & 716 & 779 & 63 \\
\hline 1967 & 908 & 1006 & 98 \\
\hline 1968 & 1021 & 1108 & 87 \\
\hline 1969 & 1247 & 1375 & 128 \\
\hline 1970 & 1474 & 1625 & 151 \\
\hline 1971 & 1564 & 1724 & 160 \\
\hline 1972 & 1712 & 1929 & 217 \\
\hline 1973 & 1662 & 1896 & 234 \\
\hline 1974 & 1544 & 1840 & 296 \\
\hline 1975 & 1375 & 1693 & 318 \\
\hline 1976 & 1396 & 1702 & 306 \\
\hline 1977 & 1488 & 1819 & 331 \\
\hline 1978 & 1434 & 1803 & 369 \\
\hline 1979 & 1339 & 1738 & 399 \\
\hline 1980 & 1377 & 1816 & 439 \\
\hline 1981 & 1290 & 1715 & 425 \\
\hline 1982 & 1370 & 1821 & 451 \\
\hline 1983 & 1368 & 1878 & 510 \\
\hline 1984 & 1476 & 2004 & 528 \\
\hline 1985 & 1612 & 2220 & 608 \\
\hline 1986 & 1698 & 2375 & 677 \\
\hline 1987 & 1680 & 2418 & 738 \\
\hline & & & \\
\hline & & & \\
\hline
\end{tabular}




\begin{tabular}{|c|c|c|c|}
1988 & 1791 & 2573 & 782 \\
\hline 1989 & 1815 & 2673 & 858 \\
\hline 1990 & 2017 & 2947 & 930 \\
\hline 1991 & 2136 & 3136 & 1000 \\
\hline 1992 & 2136 & 3135 & 999 \\
\hline 1993 & 2265 & 3357 & 1089 \\
\hline 1994 & 2454 & 3552 & 1098 \\
\hline 1995 & 2550 & 3717 & 1164 \\
\hline 1996 & 2595 & 3927 & 1335 \\
\hline 1997 & 2544 & 3966 & 1425 \\
\hline 1998 & 2541 & 3978 & 1437 \\
\hline 1999 & 2409 & 3966 & 1557 \\
\hline 2000 & 2277 & 3861 & 1584 \\
\hline 2001 & 2124 & 3708 & 1584 \\
\hline 2002 & 2127 & 3729 & 1605 \\
\hline 2003 & 2244 & 3861 & 1617 \\
\hline 2004 & 2334 & 4164 & 1827 \\
\hline 2005 & 2352 & 4200 & 1848 \\
\hline
\end{tabular}

Sources:

(a) Table W504-512 (Website address: http://www.statcan.gc.ca/pub/ 11-516x/sectionw/4147445-eng. htm) for years 1955-1973.

(b) Table 477-0014 available through CANSIM (Website address:

http://cansim2.statcan.gc.ca/ cgi-win/CNSMCGI.EXE?LANG=Eng\& DirRep=CII/\&CNSM-Fi=CII/CII_ 1-eng.htm) for years 1970-1997.

(c) CANSIM (Website address: http://library.queensu.ca/webdoc/ssdc/ xcleduc99.htm\#top) for years 1992-2005. 
Table B-4:

Explanatory Variables Lagged 6 Years in Used in the Regressions, United States

\begin{tabular}{|c|c|c|c|c|c|c|c|}
\hline Year & Conscription & $\begin{array}{l}\text { Vietnam } \\
\text { War } \\
\text { Dummy }\end{array}$ & $\begin{array}{c}\text { Korean } \\
\text { War } \\
\text { Dummy }\end{array}$ & $\begin{array}{c}\text { Research } \\
\text { and } \\
\text { Development }\end{array}$ & $\begin{array}{c}\text { Unemployment } \\
\text { Rate }\end{array}$ & Productivity & $\begin{array}{c}\text { Productivity } \\
\text { Growth }\end{array}$ \\
\hline 1944 & 1591942 & 0 & 0 & & & & \\
\hline 1945 & 945862 & 0 & 0 & & & & \\
\hline 1946 & 183383 & 0 & 0 & & & & \\
\hline 1947 & 0 & 0 & 0 & & & 42.565 & \\
\hline 1948 & 20348 & 0 & 0 & & 2.75 & 43.505 & 2.2 \\
\hline 1949 & 9781 & 0 & 0 & & 4.925 & 44.494 & 2.3 \\
\hline 1950 & 219771 & 0 & 1 & & 4.1 & 47.817 & 7.5 \\
\hline 1951 & 551806 & 0 & 1 & 8835813 & 2.35 & 49.203 & 2.9 \\
\hline 1952 & 438479 & 0 & 1 & 10662563 & 2.25 & 50.014 & 1.6 \\
\hline 1953 & 471806 & 0 & 1 & 10523810 & 2.275 & 50.923 & 1.8 \\
\hline 1954 & 253230 & 0 & 0 & 9549268 & 4.475 & 51.505 & 1.1 \\
\hline 1955 & 152777 & 0 & 0 & 10986529 & 3.375 & 54.168 & 5.2 \\
\hline 1956 & 137940 & 0 & 0 & 15645042 & 3.05 & 53.549 & -1.1 \\
\hline 1957 & 138504 & 0 & 0 & 19838552 & 3.25 & 54.298 & 1.4 \\
\hline 1958 & 142246 & 0 & 0 & 22378658 & 5.675 & 55.096 & 1.5 \\
\hline 1959 & 96153 & 0 & 0 & 32273433 & 4.25 & 57.74 & 4.8 \\
\hline 1960 & 86602 & 0 & 0 & 35977828 & 4.3 & 58.129 & 0.7 \\
\hline 1961 & 118586 & 0 & 0 & 42548722 & 5.2 & 59.743 & 2.8 \\
\hline 1962 & 82060 & 0 & 0 & 47793530 & 4.125 & 62.652 & 4.9 \\
\hline 1963 & 119265 & 0 & 0 & 57314729 & 3.925 & 64.846 & 3.5 \\
\hline 1964 & 112386 & 1 & 0 & 64484832 & 3.325 & 67.566 & 4.2 \\
\hline 1965 & 230991 & 1 & 0 & 65125887 & 2.8 & 69.884 & 3.4 \\
\hline 1966 & 382010 & 1 & 0 & 66842644 & 2.25 & 72.044 & 3.1 \\
\hline 1967 & 228263 & 1 & 0 & 69860943 & 2.025 & 72.072 & 0 \\
\hline 1968 & 296406 & 1 & 0 & 64984522 & 1.8 & 74.104 & 2.8 \\
\hline 1969 & 283586 & 1 & 0 & 61049524 & 1.675 & 73.696 & -0.6 \\
\hline 1970 & 162746 & 1 & 0 & 56768827 & 2.85 & 73.565 & -0.2 \\
\hline 1971 & 94092 & 1 & 0 & 54785026 & 3.475 & 76.131 & 3.5 \\
\hline 1972 & 49514 & 1 & 0 & 55523039 & 3.1 & 78.817 & 3.5 \\
\hline 1973 & 646 & 1 & 0 & 54159101 & 2.575 & 80.983 & 2.7 \\
\hline 1974 & 0 & 1 & 0 & 52345544 & 3.05 & 78.6 & -2.9 \\
\hline
\end{tabular}




\begin{tabular}{|c|c|c|c|c|c|c|c|}
\hline 1975 & 0 & 1 & 0 & 51848633 & 5.475 & 79.599 & 1.3 \\
\hline 1976 & 0 & 0 & 0 & 52780437 & 4.825 & 82.314 & 3.4 \\
\hline 1977 & 0 & 0 & 0 & 55412044 & 4.225 & 83.144 & 1 \\
\hline 1978 & 0 & 0 & 0 & 57217483 & 3.375 & 83.945 & 1 \\
\hline 1979 & 0 & 0 & 0 & 57674471 & 3.325 & 83.104 & -1 \\
\hline 1980 & 0 & 0 & 0 & 56199005 & 4.8 & 82.009 & -1.3 \\
\hline 1981 & 0 & 0 & 0 & 56801517 & 5.1 & 82.817 & 1 \\
\hline 1982 & 0 & 0 & 0 & 58507450 & 7.5 & 81.455 & -1.6 \\
\hline 1983 & 0 & 0 & 0 & 59537891 & 7.725 & 85.903 & 5.5 \\
\hline 1984 & 0 & 0 & 0 & 62629583 & 5.675 & 88.195 & 2.7 \\
\hline 1985 & 0 & 0 & 0 & 69472152 & 5.35 & 89.367 & 1.3 \\
\hline 1986 & 0 & 0 & 0 & 72177964 & 5.375 & 91.225 & 2.1 \\
\hline 1987 & 0 & 0 & 0 & 75596789 & 4.75 & 91.9 & 0.7 \\
\hline 1988 & 0 & 0 & 0 & 75301001 & 4.2 & 93.133 & 1.3 \\
\hline 1989 & 0 & 0 & 0 & 78414614 & 3.925 & 94.274 & 1.2 \\
\hline 1990 & 0 & 0 & 0 & 78255936 & 4.45 & 94.953 & 0.7 \\
\hline 1991 & 0 & 0 & 0 & 72736623 & 5.7 & 95.758 & 0.8 \\
\hline 1992 & 0 & 0 & 0 & 75926137 & 6.45 & 100 & 4.4 \\
\hline 1993 & 0 & 0 & 0 & 76216061 & 5.8 & 100.972 & 1 \\
\hline 1994 & 0 & 0 & 0 & 74515560 & 4.775 & 102.459 & 1.5 \\
\hline 1995 & 0 & 0 & 0 & 73979384 & 4.275 & 102.849 & 0.4 \\
\hline 1996 & 0 & 0 & 0 & 72055647 & 4.025 & 104.974 & 2.1 \\
\hline 1997 & 0 & 0 & 0 & 73086434 & 3.625 & 107.416 & 2.3 \\
\hline 1998 & 0 & 0 & 0 & 74530416 & 3.175 & 110.278 & 2.7 \\
\hline 1999 & 0 & 0 & 0 & 76870342 & 2.95 & 113.899 & 3.3 \\
\hline 2000 & 0 & 0 & 0 & 72863318 & 2.825 & 116.221 & 2 \\
\hline
\end{tabular}

Sources:

(a) Induction statistics are from the selective services (Website address: http://www.sss.gov/induct.htm).

(b) Research and Development statistics are from NSF Survey of Federal Funds for Research and Development 1951-2006 and adjusted to 2000 dollars and in thousands.

(c) Unemployment rate is annual rate for males over the age of 25 and the statistics are from the Bureau of Labor Statistics (Website address:

http://data.bls.gov).

(d) Productivity is measured as output per worker (base year 1992). Productivity growth is the annual percentage change in productivity. The statistics are from the Bureau of Labor Statistics (Website address: http://data.bls.gov). 
Works Cited

Baskir, Lawrence M. \& Strauss, William A, Chance and circumstance : the draft, the war, and the Vietnam generation. Knopf, New York : 1978

Berelson, Bernard. Graduate education in the United States McGraw-Hill, New York: 1960

Bound, John and Turner, Sarah. "Going to War and Going to College: Did World War II and the G.I. Bill Increase Educational Attainment for Returning Veterans?”' Journal of Labor Economics, University of Chicagol Press, vol. 20(4) pp 784-815.

Bowen, W. G., \& Rudenstine, N. L. 1992. In pursuit of the Ph.D. Princeton, NJ: Princeton University Press.

Bowen, William G., and Sosa, Julie Ann. Prospects for Faculty in the Arts and Sciences. Princeton, NJ: Princeton University Press, 1989.

Card, D. and Lemieux, T. 2001. “Going to College to Avoid the Draft: The Unintended Legacy of the Vietnam War.” The American Economic Review, 91 (2), 97-102

Cartter, Alan 1965 "The supply and demand of college teachers." American Statistical Association, 70-80

1966 “An Assessment of Quality in Graduate Education.” Washington: American Council on Education.

1971 "Scientific manpower trends for 1970- 1985." Science 172:132-140.

1972 "Faculty needs and resources in American higher education." Annals of the American Academy of Science 409 (November): 71-87.

1974 "The academic labor market." In M. S. Gordon (ed.), Higher Education and the Labor Market. New York: McGraw Hill.

1976 Ph.D. 's and the Academic Labor Market. Toronto: McGraw Hill

Chiswick, Barry R. 2008. "The Rise and Fall of the American Jewish PhD.” Contemporary Jewery. Vol 29, 2009, 67-84.

Cochrane and Orcutt. 1949. "Application of least squares regression to relationships containing autocorrelated error terms". Journal of the American Statistical Association 44, pp 32-61

Davis, James Warren,. \& Dolbeare, Kenneth M. 1968 Little groups of neighbours : the Selective Service System. Markham, Chicago 
Ehrenberg, Ronald G., and Panagiotis G. Mavros. 1995. "Do Doctoral Students' Financial Support Patterns Affect Their Times-To-Degree and Completion Probabilities?" Journal of Human Resources 30(3):581-609

Freeman, R.B. 1971 The Market for College-Trained Manpower (A Study in the Economics of Career Choice). Harvard University Press.

Freeman, R.B. 1975a. “Legal 'cobwebs': a recursive model of the market for new lawyers.” Review of Economics and Statistics (1975a), pp. 171-179.

Freeman, R.B. 1975b. "Supply and salary adjustments to the changing science manpower market: physics, 1948-1973.” The American Economic Review 65-1 (1975b), pp. 27-39.

Freeman, R. B., and D. W. Breneman 1974 "Forecasting the Ph.D. Labor Market: Pitfalls for Policy.” Techical Report \#2. Printing and Publishing Office, National Academy of Sciences. Washington, D.C.

Hansen, W. Lee, Harriet B. Newburger, Fred J. Schroeder, David C. Stapleton, and Douglas J. Young. 1980. "Forecasting the Market for New Ph.D. Economists." American Economic Review 70(1):49-63

Marmion, Harry A. 1968 Selective service; conflict and compromise. Wiley New York,

Long, Millard F. 1966 "Foreign Graduate Students in Economics” The American Economic Review, Vol. 56, No. 4, Part 1 (Sep., 1966), pp. 848-855

Lovitts, B. E. (2001). Leaving the ivory tower: The causes and consequences of departure from doctoral study. Lanham, MD: Rowman and Littlefield.

Savin N.E. and White K.J.(1977), "The Durbin-Watson Test for Serial Correlation with Extreme Sample Sizes or Many Regressors," Econometrica 45, p.1989-1996.

Schultz, T.W. (1975) “The Ability to Deal with Disequilibria” Journal of Economic Literature, 13, no. 3 (September. 1975): 827-46.

Scott, Frank A., Anstine, Jeffrey D., "Market Structure in the Production of Economics Ph.D.’s” Southern Economic Journal, July 1997, 307-320.

Stephan, Paula E., Black, Grant C., Adams, James D., and Levin, Sharon G., "Survey of Foreing Recipients of U.S. Ph.D.'s.” American Association for the Advancement of Science, March 2002, 2211-2212.

Youn, Ted 2005 “The Academic Job Market is Bad for All of Us.” Academe. November- 
December. 